\title{
Branduolių sintezès tyrimai Lietuvos energetikos institute
}

Eugenijus Ušpuras,

Sigitas Rimkevičius,

Egidijus Urbonavičius,

Algirdas Kaliatka,

Gintautas Dundulis,

Robertas Alzbutas,

Gediminas Stankūnas,

Mindaugas Vaišnoras,

Virginijus Vileiniškis,

Mantas Povilaitis,

Tadas Kaliatka,

Remigijus Janulionis,

Renatas Karalevičius,

Roman Voronov,

Tomas Iešmantas,

Tomas Kačegavičius

Lietuvos energetikos institutas, Branduoliniu irenginiu saugos laboratorija, Breslaujos g. 3, LT-44403 Kaunas El.paštas Eugenijus.Uspuras@lei.lt
Kol buvo eksploatuojama Ignalinos $\mathrm{AE}$, daugelis Lietuvos energetikos instituto (LEI) Branduoliniu įrenginių saugos laboratorijos (BİSL) mokslinių tyrimų buvo nukreipta branduolinių elektrinių saugos klausimams spręsti. Nuo $2006 \mathrm{~m}$. LEI įsitraukè ị mokslinius tyrimus, susijusius su branduoliu sintezès tematika. Branduoliu sintezè - tai procesas, kurio metu susijungia du lengvi branduoliai, pavyzdžiui, vandenilio izotopai deuteris ir tritis, sudarydami naują helio branduoli, o šio proceso metu išsiskiria milžiniškas energijos kiekis. Toks procesas vyksta ir žvaigždèse, o pasaulio mokslininkai sprendžia, kaip jị būtų galima suvaldyti ir pritaikyti Žemëje.

Jei $2006 \mathrm{~m}$. LEI vykdè tik nedidelį projektą, susijusį su vienu iš ITER reaktoriaus saugos aspektų, tai vèliau LEI BĮSL mokslininkai plète savo veiklos apimtis ir ịsitraukè ị naujas tyrimų sritis: neutronų pernašos procesų tyrimai, įrangos patikimumo tyrimai, ịvairiu konstrukcijų struktūrinio vientisumo tyrimai, t. t. Jau 2013 m. kartu su kitais Europos mokslinių tyrimų centrais LEI BĮSL dalyvavo rengiant kelrodị, kaip iki $2050 \mathrm{~m}$. pasiekti, kad energija būtu gaminama ir branduolių sintezès įrenginiuose. Šis kelrodis tapo pagrindu parengti programos „Horizontas 2020“ EUROfusion projektą, kurio koordinatorius yra Vokietijos mokslinių tyrimų centras, ịsikūręs Makso Planko Plazmos fizikos institute (Max-Planck Institut für Plasmaphysik). Tai pirmasis ir didžiausias ne tik finansiniu indèliu, bet ir ambicingumu Europos Sajungos mokslinių tyrimų ir inovacijų programos projektas.

Šiame straipsnyje trumpai apžvelgiama kiekviena iš tematikų, kuriose LEI BĮSL vykdè ir vykdo tyrimus nuo $2006 \mathrm{~m}$. Straipsnio pabaigoje pateikiamas LEI mokslininkų paskelbtų pagrindinių publikacijų branduolių sintezès tematika sąrašas.

Raktažodžiai: branduolių sintezè, saugos vertinimas, neutronų pernaša, įrangos patikimumas, struktūrinio vientisumo tyrimai 


\section{IVADAS}

Kol buvo eksploatuojama Ignalinos AE daugelis LEI Branduolinių i̇renginių saugos laboratorijos mokslinių tyrimų buvo nukreipta branduolinių elektrinių saugos klausimams spręsti. Instituto mokslininkams aktyviai dalyvaujant ịvairiose tarptautinese konferencijose, seminaruose ar kituose renginiuose, Europos Komisijos (EK) atstovai pastebėjo mūsų mokslininkų kompetenciją ir atkreipè dèmesi $\mathfrak{i}$ galimybes ittraukti juos $\mathfrak{i}$ branduolių sintezès tyrimus. $2006 \mathrm{~m}$. teikème paraišką ir vèliau vykdème Europos Sajungos (ES) 6-osios bendrosios mokslinių tyrimų, technologinès pletros ir demonstracinès veiklos programos (BP) projektą, skirtą ITER saugai ịvertinti. Taip pat $2006 \mathrm{~m}$. vyko derybos ir buvo pasirašyta asociacijos sutartis tarp LEI ir EK, kuri įsigaliojo nuo 2007 m. pradžios. 2006 m. lapkričio 15 d. Lietuvos energetikos institute ivvyko pirmasis projekto posedis, kuriame dalyvavo EK atstovai Y. Capouetas, M. Pipeleersas, B. Greenas ir S. J. Boothas. Prie asociacijos sutarties vykdymo prisidèjo ir Vilniaus universiteto Teorinès fizikos ir astronomijos instituto mokslininkai.

Nuo 2007 m. aktyviai dalyvaujant branduoliuc sintezės tyrimuose pavyko įsitvirtinti šioje srityje ir $2012 \mathrm{~m}$. kartu su kitais partneriais buvo pradèta rengtis naujai EK finansinei perspektyvai. Iš pradžių buvo sudarytas elektros energijos gamybos iš branduolių sintezès kelrodis, kuris ir tapo pagrindu programos „Horizontas 2020“ EUROfusion projektui.

$2014 \mathrm{~m}$. spalio 9 d. EK oficialiai pradejjo branduolių sintezès plètros projektą EUROfusion (daugiau informacijos https://www.euro-fusion.org/), kuris koordinuoja branduolių sintezès mokslinių tyrimų veiklą Europoje. Nauja dotacijos sutartis pakeitè 14 metų gyvavusią Europos branduolių sintezės plètros sutartị ir 29 dvišales asociaciju sutartis tarp Europos Komisijos bei 27 šalių mokslinių tyrimų institucijų. Dotacijos sutartis numato $424 \mathrm{mln}$. eurų finansavimą per programą „Horizontas 2020“ (Euratomas, 2014-2018), tokią pačią sumą skirs valstybès narès. Taip bus pasiektas bendras $850 \mathrm{mln}$. eurų penkerių metų biudžetas.

Tai pirmasis ir didžiausias ne tik finansiniu indèliu, bet ir ambicingumu ES mokslinių tyrimų ir inovacijų programos projektas. Jame kartu su 28 partneriais aktyviai dirba ir LEI (https://www.euro-fusion.
org/wpcms/wp-content/uploads/2014/09/FUSION-IN-EUROPE-14-2-web.pdf).

EUROfusion projekto koordinatorius yra Makso Planko Plazmos fizikos institutas (Vokietija), turintis didžiulę patirtị branduolių sintezès tyrimuose ir šiais metais pradèjęs stelaratoriaus tipo branduolių sintezès įrenginio Wendelstein 7-X (W7-X) eksploataciją. Vykdant šio ịrenginio saugos pagrindimo ir struktūrinio vientisumo vertinimo darbus aktyviai dalyvavo LEI Branduolinių įrenginių saugos laboratorijos (BItSL) mokslininkai.

Be to, LEI BĮSL nuo $2012 \mathrm{~m}$. ịsitraukè ị mokslinius tyrimus, susijusius su didžiausiame Europos Tokamak tipo įrenginyje JET (angl. Joint European Torus) vykdomais eksperimentais ir demonstracinès jègainès DEMO saugos pagrindimu.

EUROfusion projekte LEI BI̦SL mokslininkai toliau tęsia anksčiau pradètus branduolių sintezès mokslinius tyrimus. Šiame projekte instituto mokslininkai yra atsakingi už keleto užduočių koordinavimą ir igyvendinimą. I projekto veiklą itraukiami doktorantai, jaunieji mokslininkai.

Dalyvaudami branduoliu sintezès moksliniu tyrimų veikloje LEI BI̦SL mokslininkai paskelbè ne vieną publikaciją mokslinèje spaudoje, pranešimus skaite tarptautinèse mokslinèse konferencijose.

Šiame straipsnyje trumpai apžvelgiama kiekviena iš tematikų, kuriose LEI BĮSL vykde ir vykdo tyrimus nuo $2006 \mathrm{~m}$. Straipsnio pabaigoje pateikiamas LEI mokslininkų paskelbtų pagrindinių publikacijų branduolių sintezès tematika sąrašas.

\section{BRANDUOLIŲ SINTEZĖS İRENGINIŲ SAUGOS VERTINIMAS}

\section{ITER reaktoriaus saugos vertinimas}

ITER (angl. International Thermonuclear Experimental Reactor) reaktorius yra tokamako tipo branduolių sintezès eksperimentinis įrenginys. ITER - tai tarptautinis projektas, kuriame dalyvauja galingiausios pasaulio valstybès, siekiančios ilgalaikių energijos gamybos sprendimo tikslų. Šio projekto tikslas - moksliškai ir technologiškai patvirtinti, kad branduoliu sintezè gali būti naudojama energijai gaminti. ITER statomas Cadarache, Prancūzijoje, šiuo metu jau pastatyta didelè dalis pagalbinių pastatų ir pradedama montuoti įranga reaktoriaus patalpoje. 
2006 m. LEI BĮSL mokslininkai igyvendino savo pirmajji ITER saugos vertinimo projektą, kuris finansuotas pagal ES 6BP. Igyvendinto projekto tikslas buvo išanalizuoti, ar įmanomas vandenilio sprogimas neutralių dalelių pluoštų (kaitinimo pluošto ir diagnostikos pluošto) irenginiuose ir plazmos indo vakuuminiame siurblyje, ir jeigu sprogimas įmanomas, ịvertinti galimas sprogimo jegos sukeliamas apkrovas.

Vandenilio pasiskirstymo analizè atlikta COCOSYS (angl. Containment Code System) programų paketu. COCOSYS sukurtas siekiant atlikti išsamią visų svarbių procesų, vykstančių sunkiųjų avarijų metu lengvojo vandens reaktorių apsauginiuose kiautuose, analizę. Taip pat galima modeliuoti ir projektines avarijas. Nors programų paketas yra skirtas lengvojo vandens reaktorių apsauginių kiautų analizei, tačiau atlikta analizė buvo vienas pirmųjų bandymų pritaikyti COCOSYS branduolių sintezès reaktoriaus komponentams modeliuoti. Tyrimams atlikti buvo sudaryti šių ITER komponentų skaitiniai modeliai:

- plazmos indo vakuuminio siurblio;

- neutralių dalelių kaitinimo pluošto;

- neutralių dalelių diagnostinio pluošto.

Nagrinejjant oro patekimą $\mathfrak{i}$ ITER vakuumini siurblị gauta, kad dèl šio ịvykio nuo vakuuminių siurblių paviršiu ịvyksta vandenilio desorbcija ir it plazmos indą patenka $\sim 8 \mathrm{~mol}$ vandenilio. 1 pav. parodyta apskaičiuota dujų koncentracija ITER plazmos inde. Kaip matome, po $10 \mathrm{~s}$, t. y. baigiantis vandenilio įtekejimui, maksimali jo koncentracija siekia $50 \%$, o praejus $\sim 120 \mathrm{~s}$ vandenilis jau yra susimaišęs visame tūryje ir turbulencinis degimas arba sprogimas yra neimmanomas.

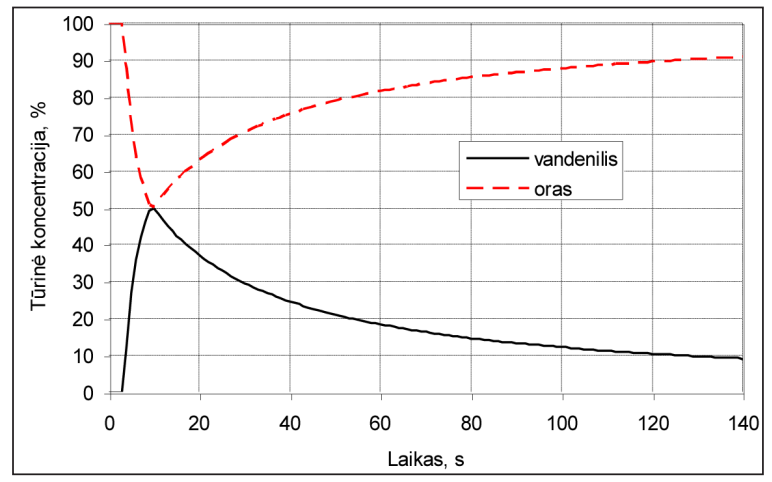

1 pav. Dujų koncentracija plazmos inde jivykus pažeidimui vakuuminiame siurblyje
Galimo vandenilio sprogimo pasekmèms ịvertinti buvo apskaičiuotas slegis plazmos inde, kuris susidaro po sprogimo. Skaičiavimai atlikti darant prielaidą, kad visa vandenilio sprogimo metu išsiskirianti energija sunaudojama slegiui ir temperatūrai pakelti. Gauta, kad didžiausias slègis (2,65 bar) (2 pav.) pasiekiamas ne tada, kai vandenilio koncentracija yra maksimali, bet jeigu sprogimas įvyksta vèliau, t. y. kai nesikondensuojančiu dujų kiekis yra didžiausias.

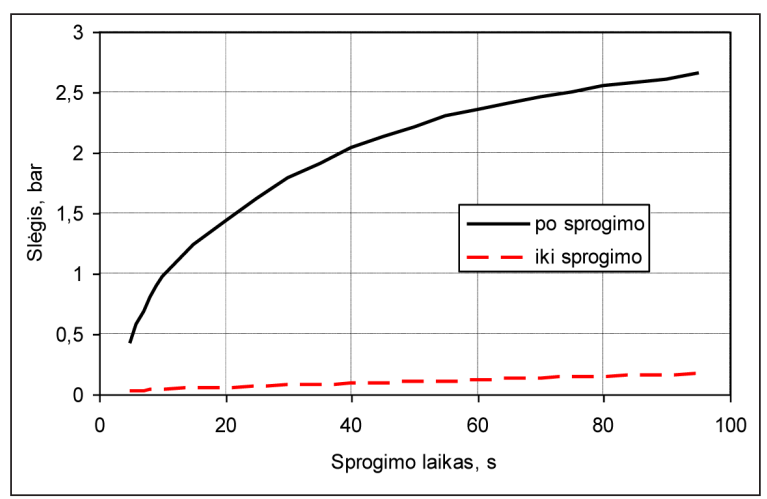

2 pav. Slègis plazmos inde po vandenilio sprogimo įvykus pažeidimui vakuuminiame siurblyje

Panašūs tyrimai buvo atlikti ir siekiant ịvertinti vandenilio sprogimo galimybę ITER kaitinimo pluošto ir diagnostinio pluošto komponentuose. Gauta, kad ịvykus avarijai maksimalus sleggis diagnostikos pluošte gali siekti 1,7 bar, kaitinimo pluošte - 1,97 bar.

Gauti rezultatai parodè, kad vandenilio sprogimo metu susidarančios apkrovos yra nepriimtinos ir būtina ieškoti priemonių tokiems ịvykiams išvengti arba sukurti apsaugos sistemas, kurios neleistu susidaryti tokioms apkrovoms, pavyzdžiui, îrengti apsaugos vožtuvą ar sukurti nedegių dujų padavimo sistemą, kuri neleistų susidaryti aukštoms vandenilio koncentracijoms.

\section{STELARATORIAUS W7-X SAUGOS VERTINIMAS}

\section{Irenginio W7-X konstrukcijos ypatumai}

W7-X kriostatas yra sudarytas iš išorinio indo, plazmos indo (PI) ir 254 atvamzdžiu jungiančių išorinị ir plazmos indus. PI - tai kriostato siena, esanti arčiausiai plazmos ir atkartojanti plazmos formą. PI fiziškai atskiria plazmą nuo likusios sistemos. 
Išorinis indas atskiria sistemą nuo išorinès aplinkos ir padeda užtikrinti gilų vakuumą, būtiną branduolių sintezès reakcijai vykti, indo viduje. Magnetų sistema išdèstyta tarp plazmos ir išorinio indų. Tarp magnetinių ričių išdèstyti atvamzdžiai. Vienintelis kelias, kuriuo iš išorès galima pasiekti PI viduje esančius komponentus, tai atvamzdžiai.

W7-X įrenginyje magnetinių laukų pagalba plazmai yra suteikiama sudètinga susukto žiedo forma (3a pav.), o kadangi plazmos indas atkartoja plazmos paviršiaus formą, todèl ir pats plazmos indas igauna sudetingą formą (3b pav.).

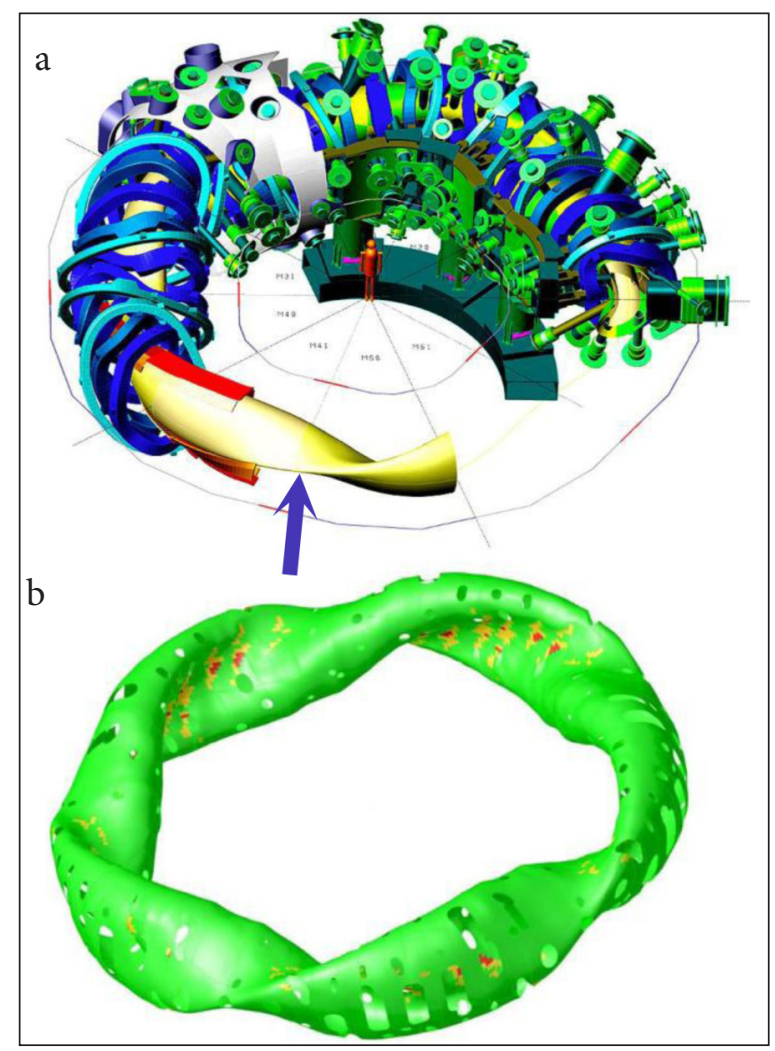

3 pav. W7-X įrenginys: a) W7-X jirenginio modelio fragmentas (plazma pažymėta rodykle), b) plazmos indas

W7-X įrenginyje šiluma generuojama degant plazmai indo viduje. Degančios plazmos temperatūra yra ypač aukšta ir gali siekti iki $60 \mathrm{MK}$ $(\sim 5 \mathrm{keV})$ temperatūros. Siekiant išlaikyti reikiamą švarią plazmą, kuri nebūtų užteršta įvairiomis kietosiomis dalelèmis (paprastai vadinamosiomis dulkėmis), susidarančiomis dèl neutronų sąveikos su medžiaga, yra įrengiami divertoriai, kurie yra vieninteliai komponentai, galintys kontaktuoti su plazma (žr. 4 pav.). Šiame paveiksle pavaizduota ir

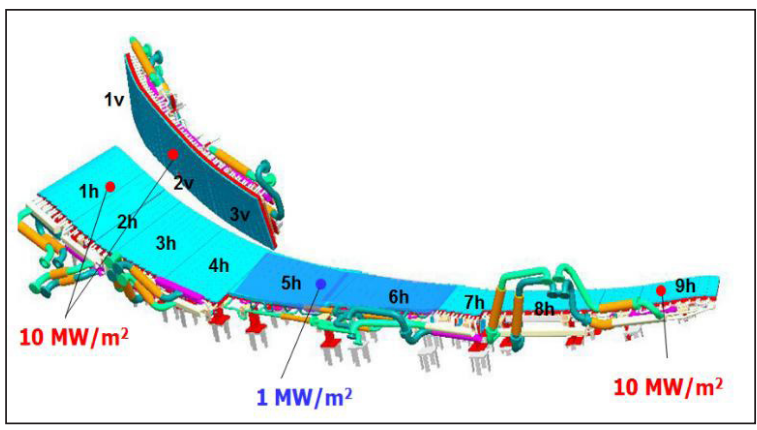

4 pav. W7-X divertorius

kokios šiluminès apkrovos tenka atskiroms divertoriaus dalims. Kiekvieną divertorių sudaro 12 „taikinio“ (angl. target) modulių. Vienas tokių modulių pavaizduotas 5 pav. Target moduli sudaro target elementai bei juos jungiantys vamzdžiai, kuriais cirkuliuoja aušinimo vanduo. Target elementas sudarytas iš anglies pluošto CFC NB31 plokštelių, $\mathrm{CuCrZr}$ vario lydinio šilumos nuvedimo elemento ir vamzdžių vandens tiekimui bei nuvedimui.

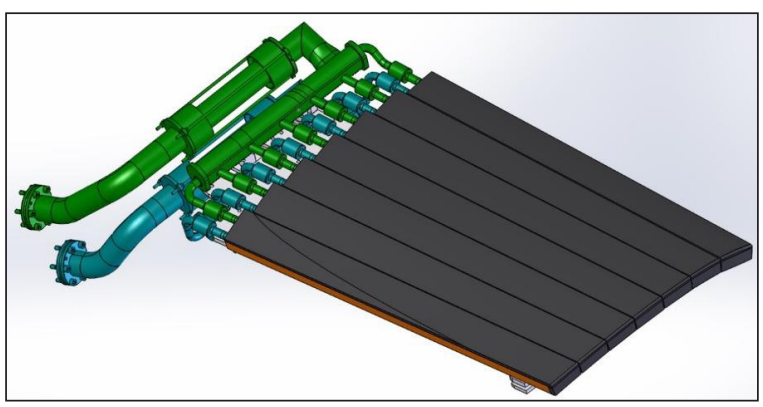

5 pav. W7-X divertoriaus Target modulis TM1H

\section{Avarijos su šilumnešio praradimu}

deterministinè analizé

2007 m. LEI BİSL mokslininkams įsitraukus it EFDA projekto veiklą prasidejo aktyvus bendradarbiavimas su Vokietijoje įsikūrusiu Makso Planko plazmos tyrimų institutu. Šio instituto Greifsvaldo padalinyje $2016 \mathrm{~m}$. pradèta stelaratoriaus tipo branduolių sintezès įrenginio W7-X eksploatacija. Taigi, LEI BİSL mokslininkai turèjo galimybę ne tik stebèti šio svarbaus įrenginio statybą, bet ir prisidèti prie saugos ivertinimo dar irenginio projektavimo etape.

LEI BĮSL mokslininkai sudarè išsamų reaktoriaus aušinimo sistemos skaitinị modelị RELAP5 programų paketui (6 pav.). Naudojant ši 


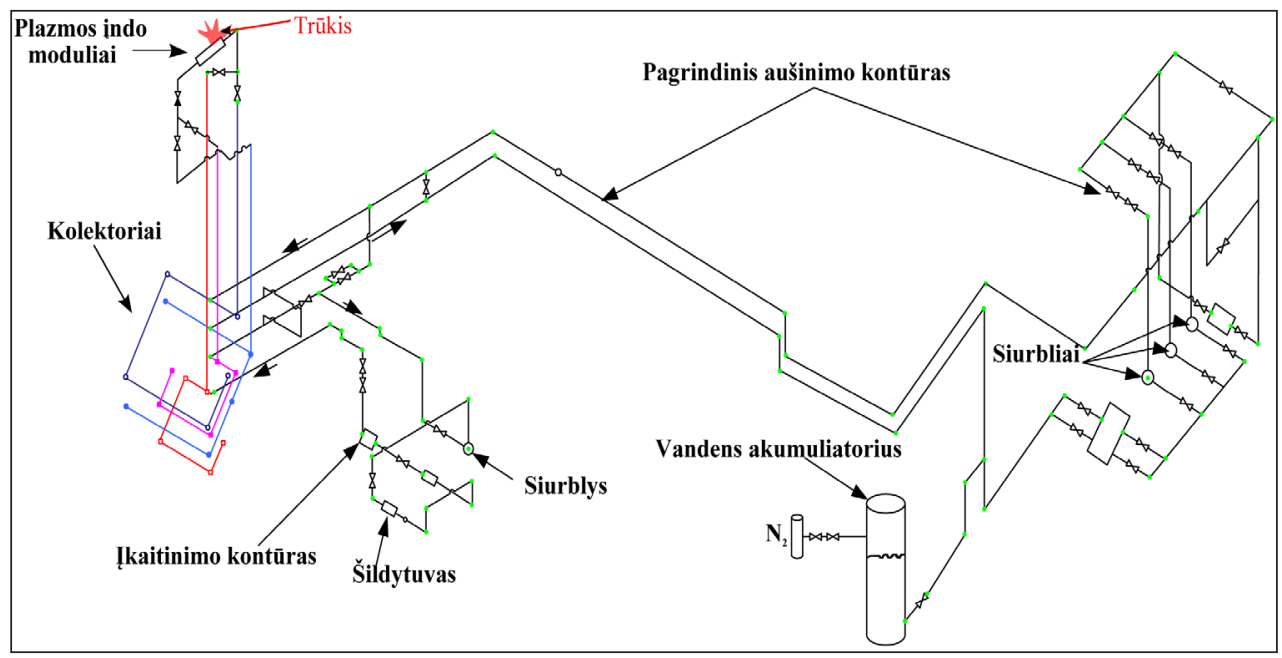

6 pav. W7-X reaktoriaus aušinimo sistemos modelis RELAP5 programų paketui

modelị buvo apskaičiuoti $\mathfrak{i}$ iš aušinimo kontūro ì plazmos indą ištekančio šilumnešio parametrai (7 pav.) Slègiui plazmos inde apskaičiuoti buvo sudarytas plazmos indo ir jo apsaugos sistemos modelis COCOSYS programų paketui (8 pav.).

Daugiausia demesio skirta W7-X saugos vertinimui, darant prielaidą, kad trūksta plazmos inde esantis $40 \mathrm{~mm}$ skersmens aušinimo kontūro vamzdis, kai reaktorius dirba kaitinimo režime, t. y. režime, kai plazma reaktoriuje dar nèra uždegta. Projektuotojų vertinimu, tokia avarija priklauso projektinių avariju tipui su sunkiausiomis pasekmèmis.

Apskaičiuotas slègio kitimas plazmos inde parodytas 9 pav. Maksimalus slègis pasiekiamas praejus $\sim 20$ s nuo avarijos pradžios. Šiuo metu pasiekus suveikimo ribą atsiveria apsaugos vožtuvas, kuris leidžia sustabdyti tolesnị slègio kilimą.

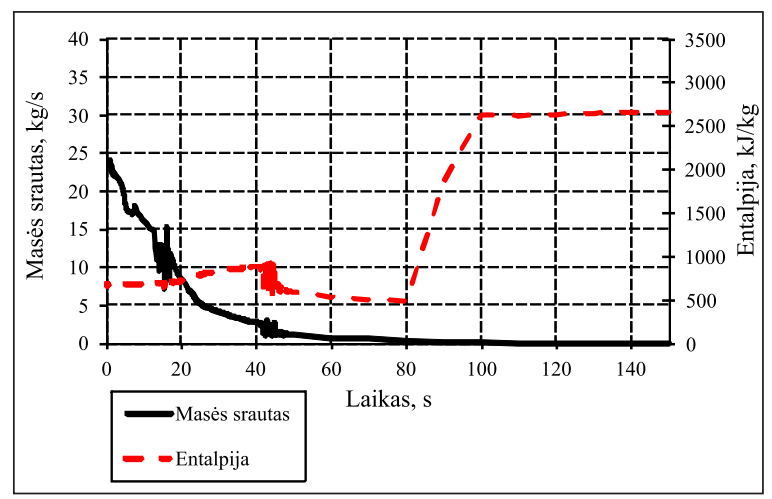

7 pav. RELAP5 programų paketu apskaičiuoti ištekančio šilumnešio parametrai
Atliktas tyrimas leido ịtikinamai pagrịsti, kad suprojektuota W7-X įrenginio apsaugos sistema užtikrina plazmos indo vientisumą, net ir įvykus sunkiausiai projektinei avarijai.

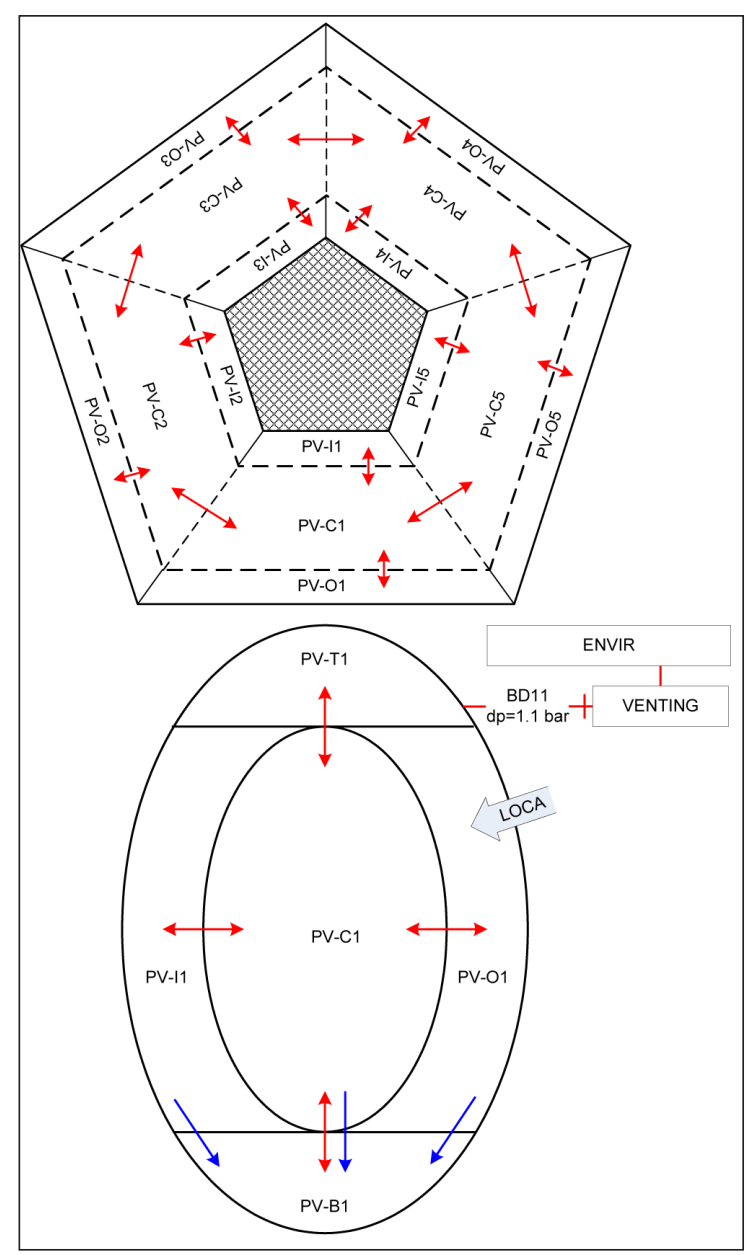

8 pav. Plazmos indo modelis COCOSYS programų paketui 


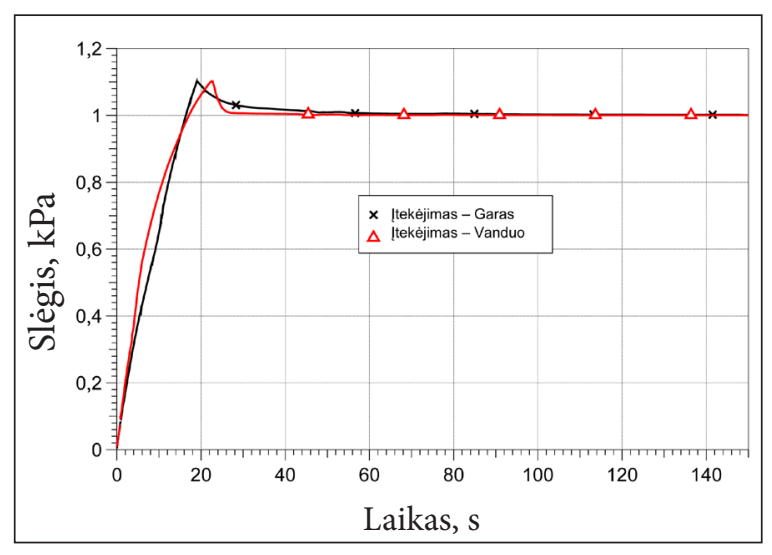

9 pav. Apskaičiuotas slègis plazmos inde jivykus $40 \mathrm{~mm}$ skersmens vamzdžio trūkiui

Pasinaudojus sudarytu skaitiniu modeliu buvo vertinamas atvejis, jeigu ịvyktų ne visiškas aušinimo sistemos vamzdžio trūkis, bet tik dalinis ịtrūkimas, ir susidarytų $2 \mathrm{~mm}$ skersmens plyšys. Gauta, kad tokiu atveju sleggio kilimas plazmos inde yra lètas, automatinè apsaugos sistema gautų signalą dèl slègio padidèjimo plazmos inde ir uždarytų apsaugos vožtuvą praejjus $\sim 1 \mathrm{~min}$. po plyšio susidarymo (10 pav.). Tačiau būtina atkreipti dėmesí, kad dèl ịtekančio vandens reaktoriuje plazma būtų užgesusi jau iki šio slègio padidejjimo signalo.

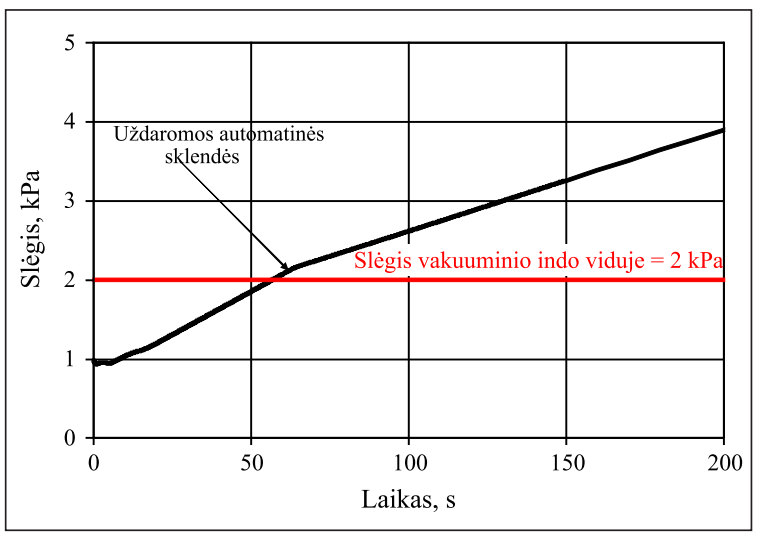

10 pav. Slègio kitimas plazmos inde j̨vykus daliniam vamzdžio trūkiui

\section{DEMO reaktoriaus saugos vertinimas}

DEMO reaktoriaus saugos klausimus LEI BĮSL mokslininkai pradèjo nagrinèti dar $2013 \mathrm{~m}$. vykdydami EFDA projektą. $2014 \mathrm{~m}$. prasidejus EUROfusion projektui DEMO saugos klausimų sprendimas tapo pagrindine veikla.
Viena užduočių yra kompiuterinių programų paketų, naudojamų branduolių sintezès reaktorių saugos analizei, apžvalga. Ši užduotis vykdoma kartu su Karlsrūhès technologijos institutu (Vokietija) ir ENEA (Italija). Atliekant šią užduotị yra apžvelgiami visi šiuo metu pasaulyje naudojami programų paketai, ịvertinami jų privalumai ir trūkumai, siekiant atlikti kokybišką DEMO reaktoriaus saugos vertinimą, nustatomos galimybès šiuos programų paketus atnaujinti ir pritaikyti vertinant DEMO reaktoriaus saugą. Visi programų paketai sugrupuoti pagal tai, ar jie skirti tik atskiriems reiškiniams ir sistemoms modeliuoti, ar jie gali būti taikomi bendrai visai sistemai aprašyti ir modeliuoti. Prie tokių atskiroms sistemoms aprašyti tinkamų programų paketų priskiriamas, pavyzdžiui, MAGS, kurio paskirtis tirti magnetuose vykstančius reiškinius, kurie yra svarbūs dèl to, kad susidarius magnetiniam išlydžiui gali būti pažeista plazmos indo konstrukcija. Šiuo metu pagrindinis integralusis programų paketas, taikomas branduolių sintezès reaktoriu tyrimams, yra JAV sukurtas MELCOR. Taip pat JAV sukurtas programų paketas RELAP5-3D turi keletą specialių modelių, reikalingų branduolių sintezès ịrenginiams tirti. Šiuo metu Europoje aktyviai tobulinamas programų paketas ASTEC, kuris jau turi kai kuriuos modelius, pavyzdžiui, kietujjų dalelių pernašą, būtinus branduolių sintezès reaktoriams tirti. Atliekant šią užduotị pastebèta, kad kol kas nèra nei vieno programų paketo, kuris leistų atlikti visapusišką DEMO reaktoriaus saugos vertinimą.

LEI BĮSL mokslininkai EUROfusion projekte buvo atsakingi už kokybės užtikrinimo metodikos, kuri būtų taikoma atliekant DEMO reaktoriaus saugos pagrindimą, parengimą. Ši metodika buvo parengta 2015 metais. Dabar vykdomi darbai siekiant sudaryti atliekamų deterministinių tyrimų neapibrěžčiu ịvertinimo metodiką. Šie darbai dar tik pradèti vykdyti kartu su partneriais iš CIEMAT (Ispanija).

LEI BĮSL mokslininkai įdèjo daug pastangų atlikdami išsamią DEMO reaktoriaus sistemų analizę. Atlikta divertoriaus ir šiluminio jègainès balanso sistemų FFMEA (angl. Functional Failure Mode and Effect Analysis) analizè dviems neutronų energiją sugeriančio apvalkalo (angl. blanket) variantams: HCLL (Helium Cooled Lithium Lead) apvalkalas ir DCLL (Dual Coolant Lithium 
Lead) apvalkalas. Taip pat FFMEA analizè atlikta Bryderio sistemai (angl. Breeding system), šiluminių ekranų (angl. Thermal shields) ir kriostato sistemai DEMO reaktoriui su HCLL tipo apvalkalu. Šių atliktų tyrimų tikslas yra nustatyti pagrindinius avarijų scenarijus, kurie toliau turès būti nagrinejjami deterministiniais metodais.

Vienas iš pagrindinių saugos klausimų yra radioaktyviựų medžiagų šaltinis. Spendžiant ši klausimą yra renkama ir apibendrinama informacija apie tričio ir kietụjų dalelių kiekị bei nusèdimą ivvairiose sistemose. Avarijos atveju šios radioaktyviosios medžiagos galètų patekti i patalpas ir í aplinką, todèl būtina žinoti jų kiekius, siekiant išsamaus saugos ịvertinimo. Kol kas šie kiekiai negali būti tiksliai nustatyti, nes dar nèra patvirtinto DEMO reaktoriaus projekto.

Šiais metais EUROfusion projekte pradèta vykdyti dar viena užduotis - deterministinè avarijų analizè. Čia taip pat dalyvauja ir LEI BĮSL mokslininkai, jie tyrimus atlieka su ASTEC programų paketu, tačiau kol kas dar nèra rezultatų, kuriuos būtų galima paskelbti. Numatyta nagrinèti atvejị, kai šilumnešis ị plazmos indą įteka ịvykus trūkiui divertoriuje.

\section{Neutronų pernašos ir jonizuojančiosios} spinduliuotès sklaidos procesų tyrimai europiniuose branduolių sintezès ịrenginiuose Neutronų srauto nulemta medžiagų aktyvacija ir skilimo šiluma yra vienos svarbių branduolių sintezès reaktorių charakteristikos, kurias būtina įvertinti, kad būtų užtikrintas saugus reaktorių eksploatavimas iki galutinio jų eksploatavimo nutraukimo. LEI BĮSL mokslininkų vykdomuose darbuose aprašomi WCLL (angl. Water Cooled Lithium Lead) apvalkalo moduliui skirti aktyvacijos ir skilimo šilumos skaičiavimai. Be WCLL modelio (žr. 11 pav.), atlikta ir lyginamoji analizè su kitomis Europos DEMO apvalkalo moduliu koncepcijomis DCLL (angl. Dual Coolant Lithium Lead), HCLL (angl. Helium Cooled Lithium Lead) ir HCPB (angl. Helium Cooled Pebble Bed), taikant trimati neutronu pernašos skaičiavimų modelį. Išanalizuotas platus laiko intervalas po neutronų apšvitos nutraukimo, vadinamojo aušimo periodu, kuris parenkamas atsižvelgiant $\mathfrak{i}$ priežiūros, saugumo ir atliekų tvarkymo reikalavimus.

Kaip minèta, daugiausia dèmesio buvo skirta WCLL apvalkalo modulio skilimo šilumos ir aktyvacijos skaičiavimams bei analizei, įvertinant tiek atskirus modulius, tiek ir suminę jų itaką. Aktyvacijos skaičiavimai buvo atlikti visoms WCLL modulio struktūroms. Apvalkalo aktyvacijos analizè atlikta penkioms pagrindinèms komponentèms: volframo šarvo apsauginiam sluoksniui, pirmajai ir horizontaliajai sienelei, tričio generavimo moduliui ir atraminei plokštelei. Be to, tričio generavimo moduliui iš Eurofer ir $\mathrm{LiPb}$ medžiagu itaka buvo įvertinta atskirai. Centrinio (ekvatorinio) modulio, esančio tolimesnèje nuo solenoido plazmos indo dalyje, analizès metu buvo nustatyta skirtingose komponentèse

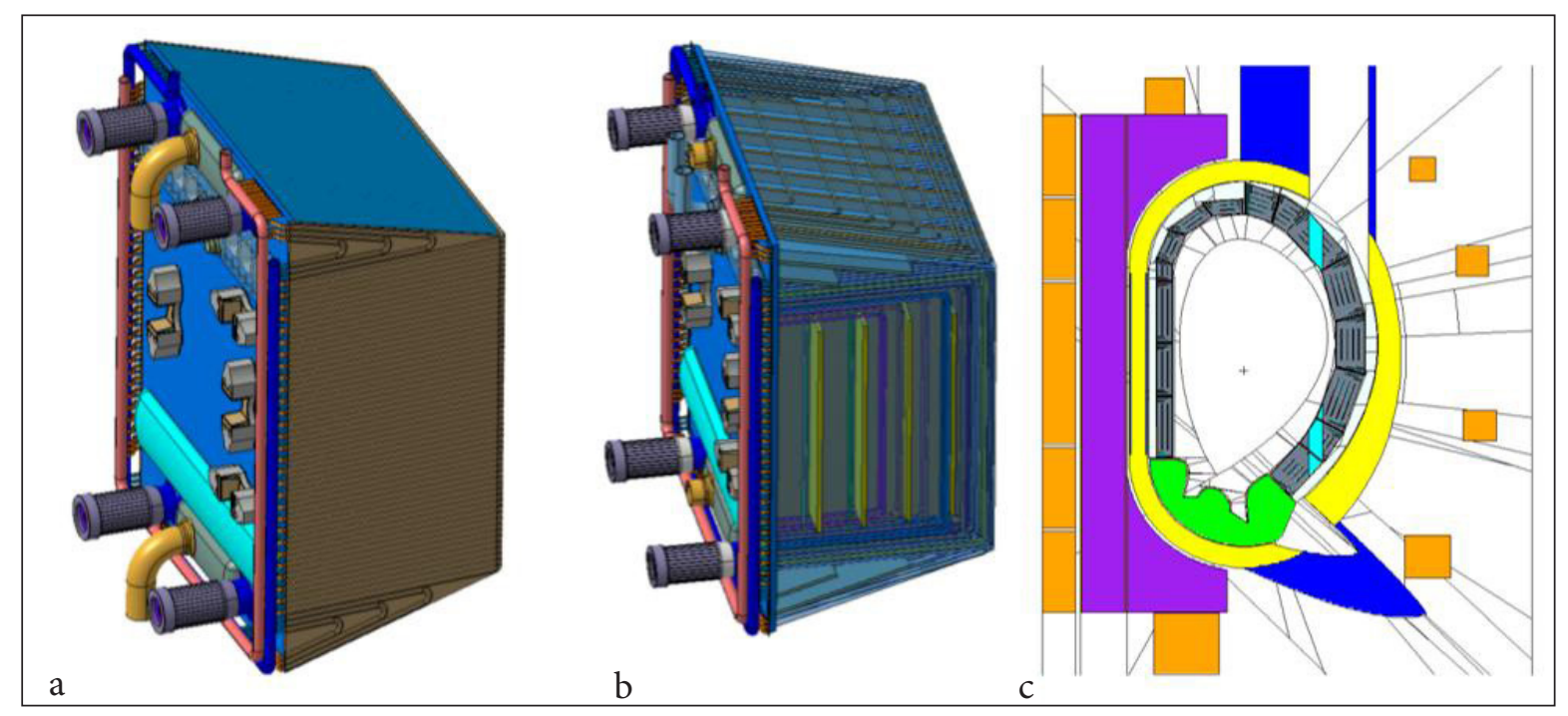

11 pav. WCLL koncepcinis modelis: a) išorinè struktūra; b) vidinè struktūra; c) MCNP modelis 
susidariusios skilimo šilumos įtaka bendrajai vertei ir nustatyti svarbiausi izotopai. Neutronų pernašos skaičiavimams panaudotas MCNP5 programų paketas su JEFF-3.1.1 duomenų biblioteka. Aktyvacijos skaičiavimai atlikti FISPACT programų paketu naudojant EAF-2010 duomenų biblioteką.

Atlikus WCLL modulio aktyvacijos skaičiavimus atskiriems komponentams, nustatyti izotopai, turintys didžiausios ittakos bendram aktyvumui. Nustatyta, kad grynojo volframo šarvui W-187 izotopas turi didžiausios įtakos po kelių dienų nuo apšvitos nutraukimo, W-185 izotopo ittaka dideja ilgejant aušimo periodui, o po metų šis izotopas lemia didžiają dalį aktyvumo (12 pav.).

Nagrinèjant skilimo šilumos išsiskyrimą ant pirmosios sienelès (13 pav.) gauta, kad Mn-56 ir W-187 izotopai vyrauja apšvitos nutraukimo pradžioje, o Fe-55 ir kiti izotopai yra reikšmingi viso aušimo metu. Tričio generavimo moduliui Mn56 ir W-187 izotopai išlieka aktyvūs visu nagrinètuoju laikotarpiu, Ta-182 izotopas irgi turi svarios ìtakos minètuoju laikotarpiu.

Panašiai kaip ir WCLL, DCLL modulio suminé skilimo šiluma (pašalinus triț) yra 23$12 \mathrm{MW}$ po vienos valandos aušimo ir mažesnè negu $1 \mathrm{MW}$ po dviejų mènesių. Po metų skilimo šiluma yra apie $0,3 \mathrm{MW}$, po 100 ir po 1000 metų ji atitinkamai nukrinta iki 4,5 ir 3 W. Nagrinëjant aktyvumo vertes, bendras aktyvumas kinta nuo $1 \cdot 10^{14} \mathrm{iki} 1 \cdot 10^{12} \mathrm{MBq}$ (10 metų laikotarpis). 100 metų ir ilgesnių laikotarpių bendras aktyvumas krinta atitinkamai nuo $2 \cdot 10^{8}$ iki $10^{7} \mathrm{MBq}$. Kaip ir tiketasi, centriniai apvalkalo moduliai pasižymi didžiausiu aktyvumu ir skilimo šiluma: toliau nuo solenoido esantys moduliai pasižymi didesnèmis suminèmis vertemis, $o$ arčiau esantys moduliai - didesnèmis tūrinèmis vertèmis. Aktyvuotas LiPb (neatsižvelgiant $\mathfrak{i}$ tritį) sudaro didžiąją dalį bendrosios skilimo šilumos tiek po 1 sekundès, tiek po 100 metų galutinio neutronų apšvitos nutraukimo. Likusiais laikotarpiais tričio generavimo modulio Eurofer plienas pasižymi didžiausiomis skilimo šilumos vertemis. Nagrinėjant aktyvumą, LiPb (neatsižvelgiant $\mathfrak{i}$ tritį) sudaro didžiąją dali bendrojo aktyvumo po 1 sekundès nuo apšvitos nutraukimo, taip pat ir po 100 bei 300 metų aušimo laikotarpių. Kaip ir skilimo šilumos atveju, Eurofer vyrauja likusiu aušimo laikotarpiu. Pagalbinèse struktūrose suminès skilimo šilumos vertès yra nuo $6 \cdot 10^{2} \mathrm{iki}$ $1 \cdot 10^{2} \mathrm{~kW}$, praejus 1 dienai po apšvitos nutraukimo; apie $10 \mathrm{~kW}$ po metų; krinta iki $3 \cdot 10^{-4} \mathrm{~kW}$ po 1000 metu aušimo periodų. Nagrinëjant aktyvumą suminè verté sieké $3 \cdot 10^{12}-1 \cdot 10^{12} \mathrm{MBq}$ po vienos dienos ir apie $3 \cdot 10^{11} \mathrm{MBq}$ po metų.

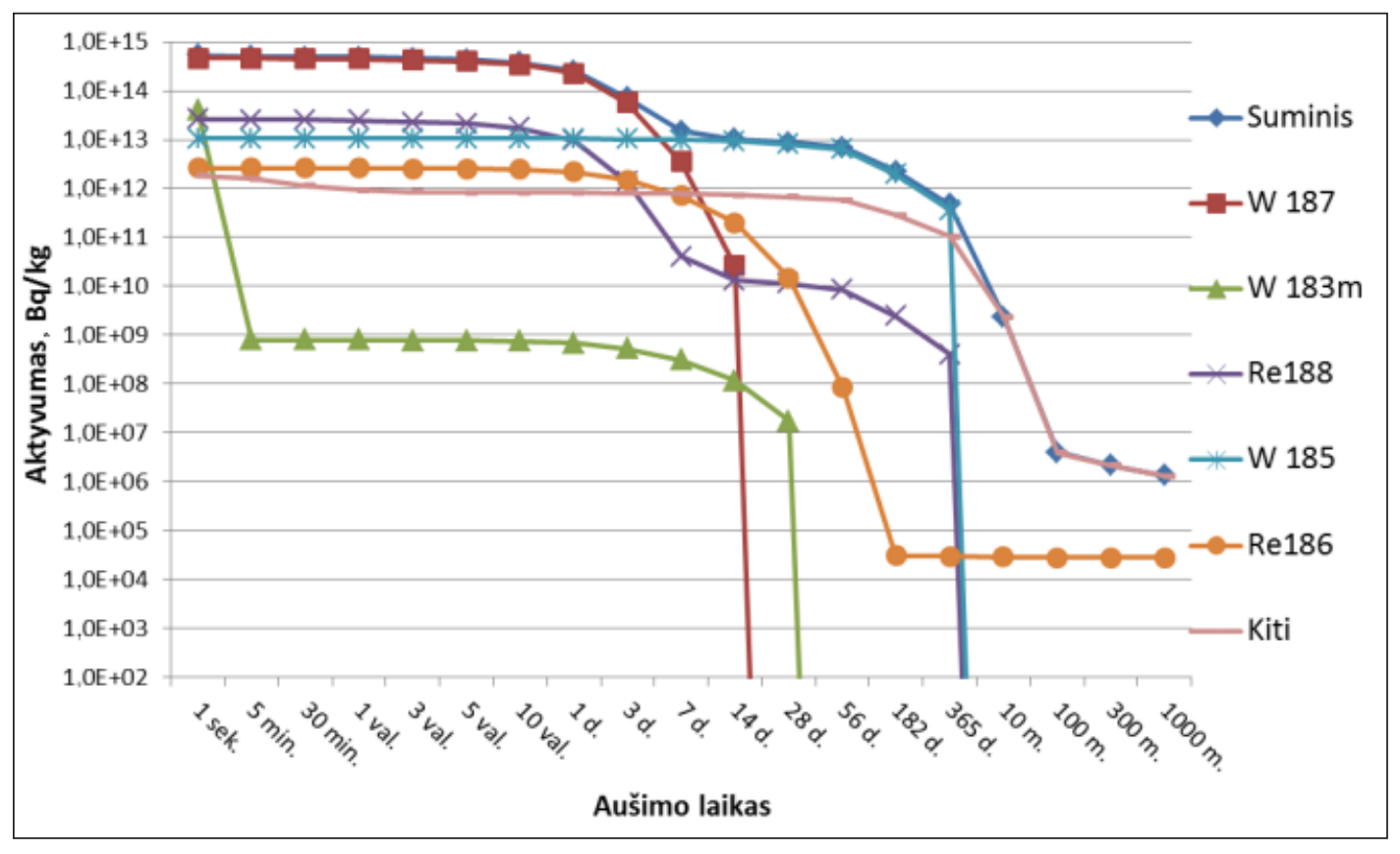

12 pav. WCLL volframo šarvo izotopų aktyvumas 


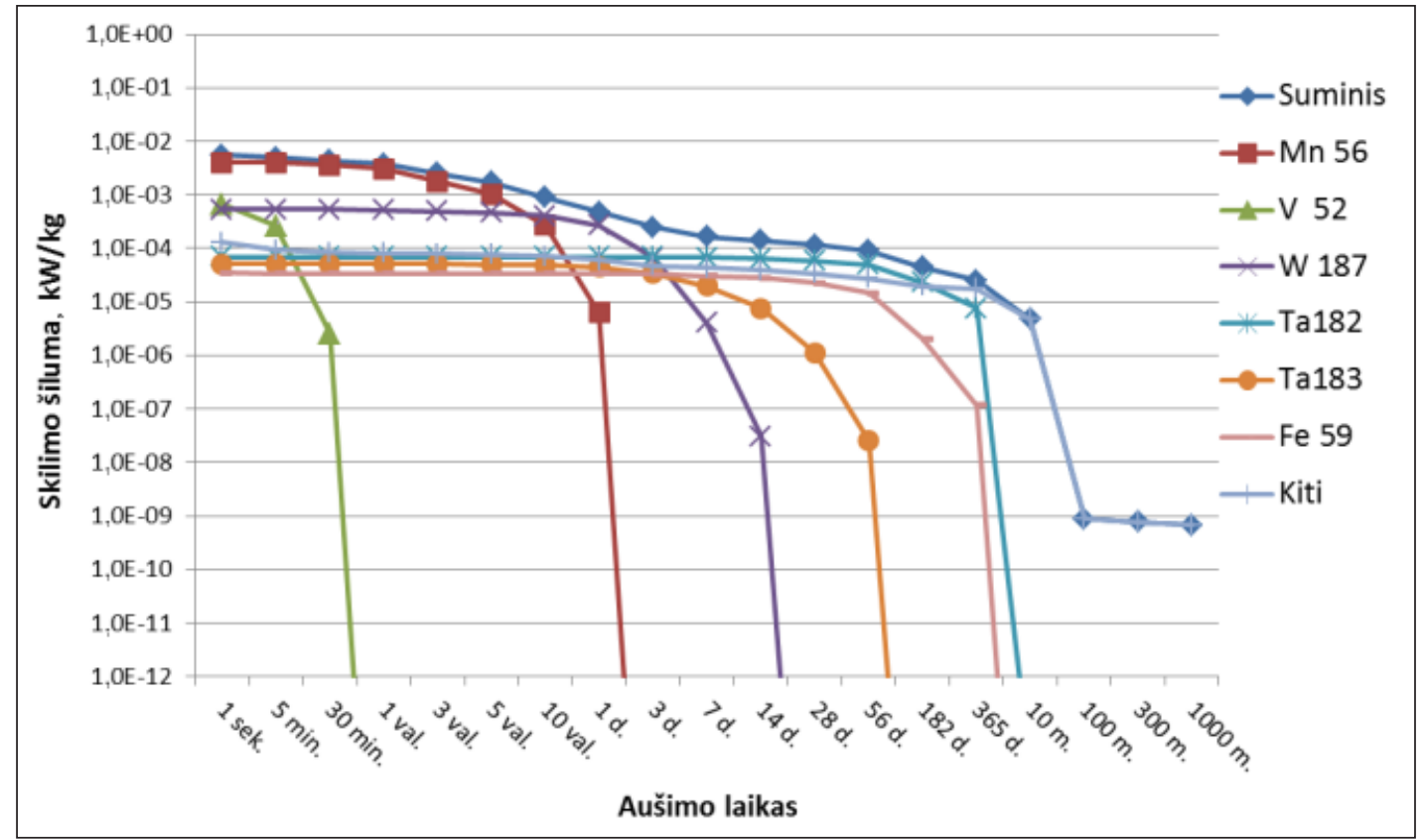

13 pav. WCLL pirmosios sienelès izotopų skilimo šiluma

Po 1000 metų aušimo laikotarpio ji krinta iki $4 \cdot 10^{6} \mathrm{MBq}$. Abejoms charakteristikoms nagrinètais laiko intervalais arčiau solenoido esantis apvalkalo modulis pasižymejo didesnèmis vertèmis negu tolimesnis modulis.

Apibendrinant gautus rezultatus paaiškèjo, kad WCLL (kaip ir DCLL) turi didžiausias ( 2-3 eilèmis didesnes) sumines skilimo šilumos vertes praèjus 100 metų nuo neutronų apšvitos nutraukimo, o pagrindiniai izotopai volframo šarve yra W-187 ir W-185. Nustatyti vyraujantys izotopai Eurofer pliene pasirode esantys $\mathrm{Fe}-55, \mathrm{Mn}-56, \mathrm{Cr}-51$, $\mathrm{W}-187$, Ta-182, kai PbLi junginyje (neskaitant tričio) - Pb-207 ir Pb-203. Galiausiai, HCLL ir HCPB apvalkalas pasižymi mažesne skilimo šiluma, palyginti su WCLL apvalkalu, vertinant bendrą skilimo šilumą (17,5 MW) praejjus 1 sekundei po neutronų apšvitos nutraukimo (žr. 14 pav.).

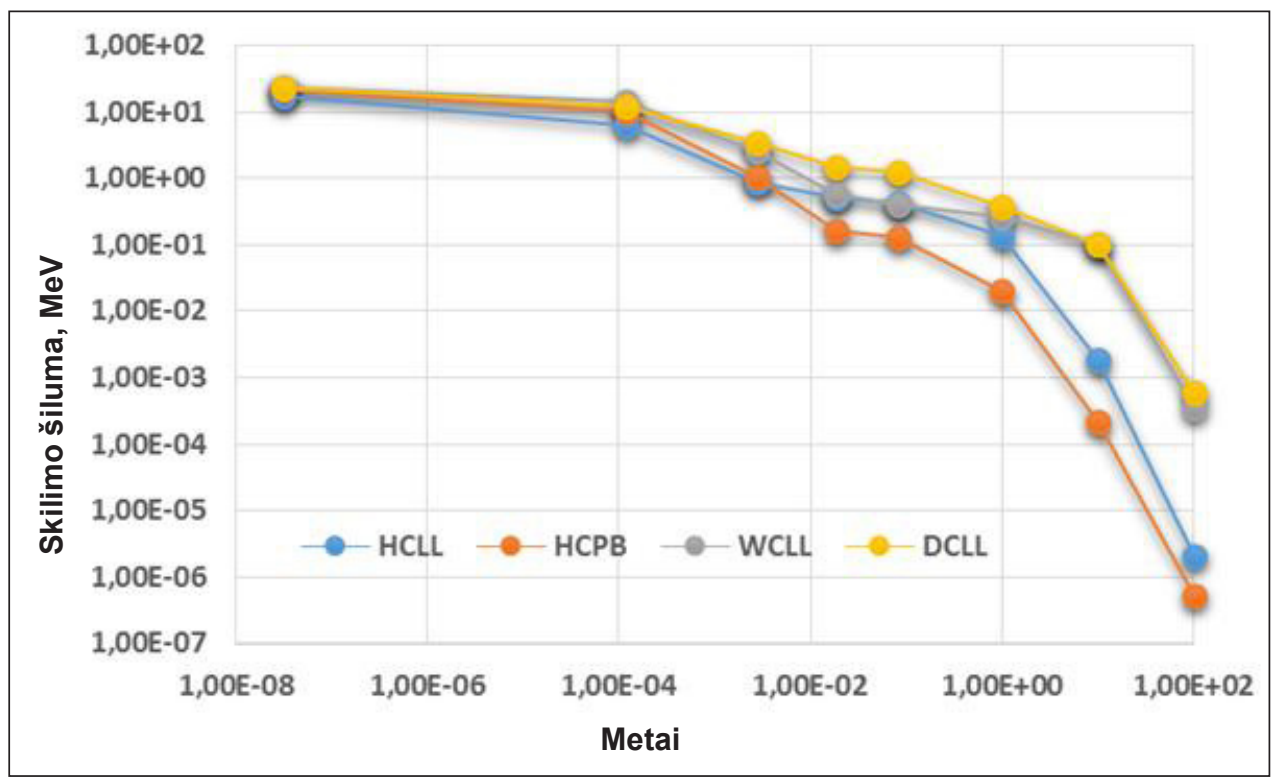

14 pav. WCLL modulio skilimo šilumos palyginimas su kitomis klojinių modulių koncepcijomis 
JET (Joint European Torus) šiuo metu yra didžiausia veikianti branduolių sintezès tyrimų bazè Europoje, kurios indèlis yra svarbus ruošiantis statomo ITER tokamako eksploatacijai. $2017 \mathrm{~m}$. JET prasidès nauja deuterio-tričio kampanija (DTE2), kurios neutronų išeiga bus 10 kartų didesnè negu ankstesnèse DT kampanijose (JET ir TFTR). Pagal EUROfusion JET3 darbų paketą, ITER reaktoriaus plazmos indo komponenčių medžiagų bandiniai bus apšvitinami JET įrenginyje DTE2 kampanijos metu. Parinktos medžiagos yra ITER-lygio W, Be, $\mathrm{CuCrZr}, 316 \mathrm{~L}(\mathrm{~N})$, taip pat funkcinès medžiagos, kurios bus naudojamos diagnostikos ir kaitinimo sistemų elementuose. LEI atlikta analizè leido ivertinti po neutronų aktyvacijos atsiradusios antrinès spinduliuotès ittaką radiacijai jautriems eksperimentinès įrangos komponentams. Anksčiau minètos medžiagos bus apšvitintos realiomis sąlygomis DT kampanijos metu vidinès ir išorinès ilgalaikès apšvitos stotyse (I-ILTS ir O-LTIS), kurios bus imontuotos JET plazmos indo viduje, ekvatorineje sienelès dalyje toliau nuo solenoido dèl šioje vietoje prognozuojamo didžiausio neutronų srauto. Vidinè LTIS dèžè parodyta 15 pav. ir yra pagaminta iš volframo, AISI316 bandinių laikikliu su tiriamujuc medžiagų bandiniais. Ruošiantis DTE2 eksperimentams, neutronų srauto spektras LTIS lokalizacijoje buvo išmatuotas naudojant dozimetrines folijas, aktyvuotas $2015 \mathrm{~m}$. JET DD kampanijos metu.

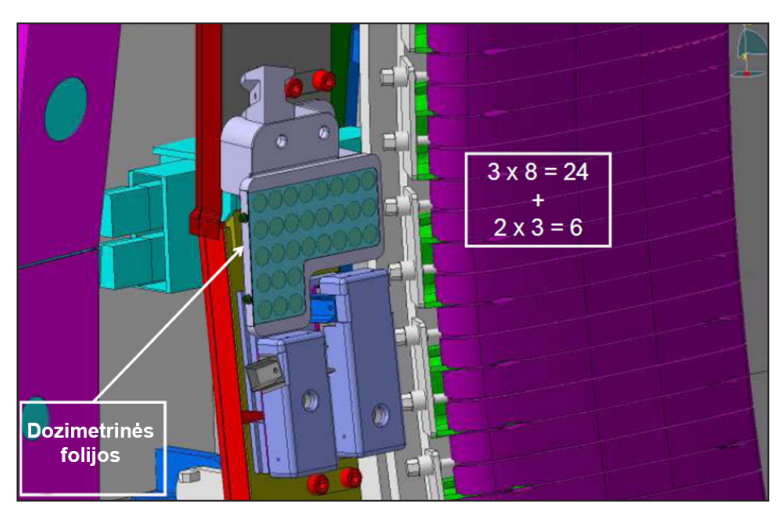

15 pav. Vidinès ilgalaikès apšvitos stotis I-LTIS (CAD modelis)

Po DTE2 apšvitos bus išmatuotas struktūrinių medžiagų aktyvumas ir nustatyti funkcinių medžiagų fizinių savybių pakitimai. Be vidinès ilgalaikès apšvitos stoties I-LTIS, kuri jau yra naudojama JET, taip pat bus įmontuota išorinè apšvitos stotis O-LTIS (16 pav.), kadangi DT kampaniju metu yra galimas bandinių užteršimas tričiu. Taip pat O-LTIS nebūtinas nuotolinis valdymas diegimo ir šalinimo metu. LEI nustatė galimus bandinių aktyvumus ir dozių galias (I-O)LTIS komponentėms po neutronų apšvitos DD ir DTE2 kampanijų metu. Skaitiniame modelyje daroma prielaida, kad ITER struktūrinių ir funkcinių medžiagų bandiniai buvo apšvitinti dideliais $14 \mathrm{MeV}$ neutronų srautais (O-I)LTIS lokalizacijose. Šioje pozicijoje neutronu srautas yra didžiausias (iki $10^{20} \mathrm{n} / \mathrm{m}^{2}$, palyginti su sumine $1,7 \cdot 10^{21}$ neutronų išeiga), kaip ir dislokacijų kiekis, tenkantis atomui $\left(10^{-5} \mathrm{dpa}\right)$. Bandinių aktyvumas ir dozés galios skaičiavimai po neutronų apšvitos buvo atlikti naudojant FISPACT-2010 programų paketą su EAF-2010 duomenų biblioteka.

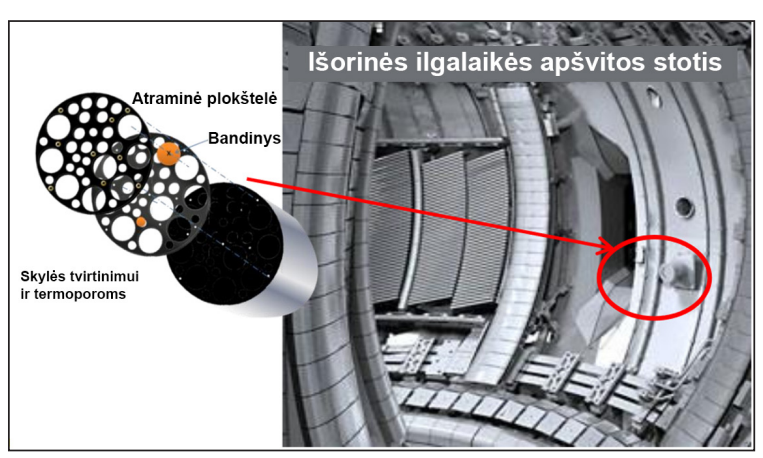

16 pav. Išorinės ilgalaikès apšvitos stotis 0-LTIS ir pozicija JET plazmos inde

Siekiant nustatyti radiacinius medžiagų parametrus JET apšvitos atveju, buvo įvertinti trys galimi scenarijai, kurių vienas DD (Deuterio-Deuterio) trunka 4 mėnesius ir jam yra priskiriamas suminis $2 \cdot 10^{19}$ DD neutronų skaičius, o DT (Deuterio-Tričio) atvejais nagrinëjami du scenarijai:

1) 6 mènesių trukmè su bendru $3 \cdot 10^{20} \mathrm{DT}$ neutronų skaičiumi;

2) 6 mènesių trukmé su bendru $1,7 \cdot 10^{21} \mathrm{DT}$ neutronų skaičiumi.

Pasitelkus aprašytą metodiką, išnagrinètos svarbiausios branduolių sintezès reaktoriaus ITER funkcinès ir konstrukcinès medžiagos, pavyzdžiui, Sapphire $\left(\mathrm{Al}_{2} \mathrm{O}_{3}\right)$, YAG, ZnS, Spinel, KUI1, KS-4V, $\operatorname{ALON}\left(\mathrm{Al}_{22} \mathrm{O}_{30} \mathrm{~N}_{2}\right)$, ALON-23 $\left(\mathrm{Al}_{23} \mathrm{O}_{28} \mathrm{~N}_{5}\right)$, ALON$67\left(\mathrm{Al}_{67} \mathrm{O}_{87} \mathrm{~N}_{9}\right)$, ALON-68 $\left(\mathrm{Al}_{68} \mathrm{O}_{64} \mathrm{~N}_{12}\right)$, Al-Bronze, Alloy 660, Be(S-65C), CuCrZr, JJ1, Nb $\mathrm{Sn}, \mathrm{NbTi}$, OF-CU, SS-304 (Borated), SS316L(N), SS316L(N)IG, SS316L, XM-19, $\mathrm{ZrO}_{2}$ ir kt. 
Baigus apšvitą neutronais aktyvumas ir dozių galia nustatyta intervalais nuo neutronų pluoštelio išjungimo iki metų aušimo. Atlikus išsamią analizę nustatyti vyraujantys radioizotopai, kurie prie bendros aktyvumo ar dozès vertès prisidèjo bent $1 \%$ ar didesnèmis vertès dalimis. Paaiškejo, kad penkios didžiausiu aktyvumu pasižymėjusios medžiagos yra SS-304 (Borated), ZnS, SS316L (žr. 17 pav.) $\mathrm{Nb}_{3}$ Sn (žr. 18 pav.) ir XM-19.

Taigi, branduolių sintezès įrenginiuose degant plazmai didžioji dalis energijos tenka neutronams, kurie ją perneša į radiaciniu požiūriu jautrius komponentus, todèl išsamus neutronų pernašos metu vykstančių fizikinių procesų tyrimas yra priskiriamas prie svarbiausių uždavinių projektuojant ir eksploatuojant branduolių sintezès įrenginius. LEI BĮSL mokslininkų atliekamuose tyrimuose neutronų srautų skaičiavimai papildomi ịtraukiant radiacinès saugos, dozimetrijos, biologinès apsaugos nuo spinduliuotés aspektus.

LEI BĮSL mokslininkų intensyviai atliekamų branduolių sintezės reaktoriuose DD ir DT reakcijų metu susidarančių neutronų, jų sąveikos su medžiagomis ir sukelto aktyvumo bei dalijimosi šilumos ir dozès galios procesų tyrimų duomenys yra ir bus aktualūs eksploatuojant ir projektuojant europinius branduolių sintezès įrenginius JET, ITER ir DEMO.
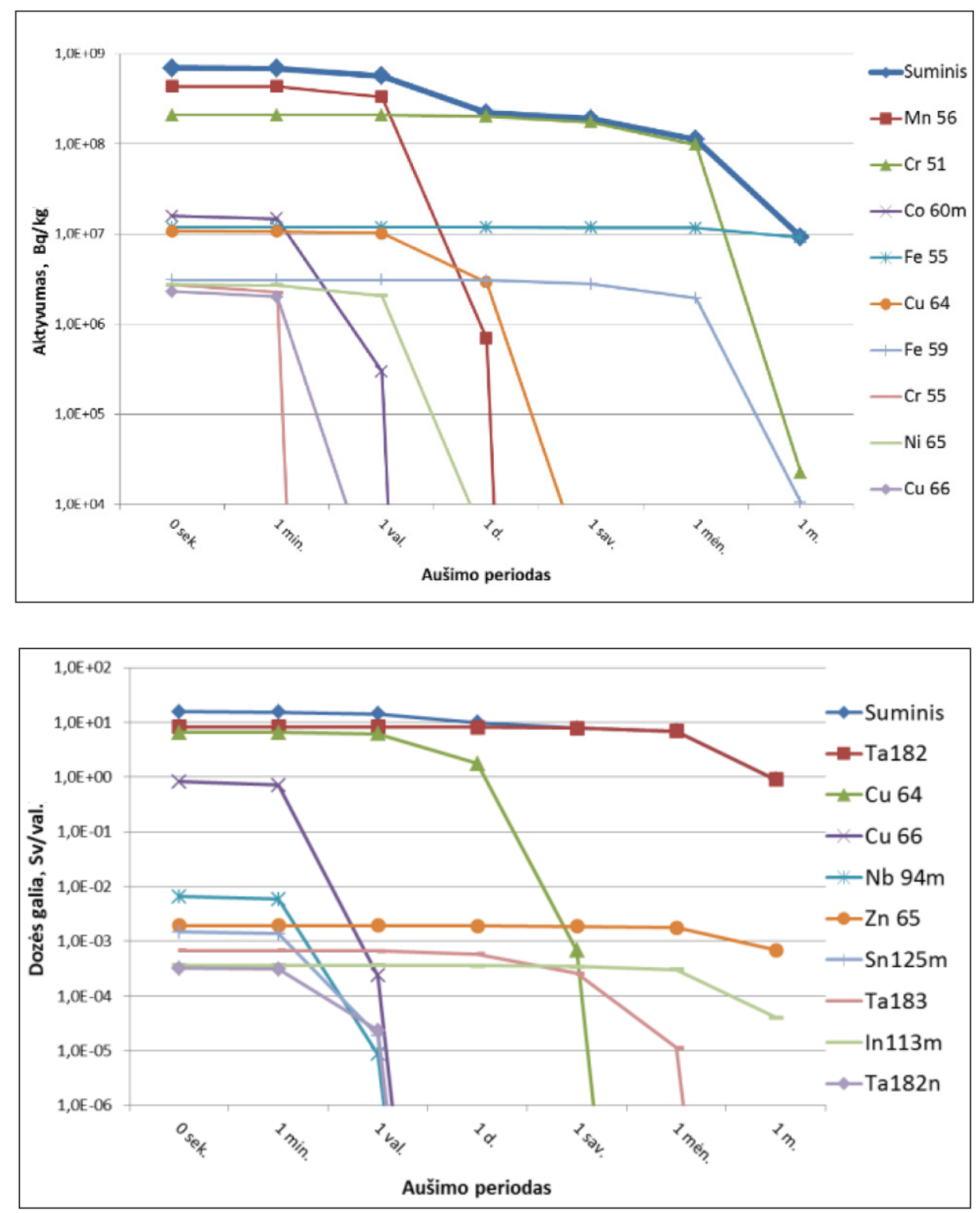

17 pav. SS316L(N)-IG aktyvumas po DD apšvitos

18 pav. $\mathrm{Nb}_{3} \mathrm{Sn}$ dozès galia po DT apšvitos 


\section{BRANDUOLIŲ SINTEZĖS REAKTORIŲ VAMZDYNŲ IR SLĖGIO INDŲ STRUKTŪRINIO VIENTISUMO TYRIMAI}

\section{W7-X struktūrinio vientisumo tyrimai}

W7-X projektuotojų prašymu buvo atlikta vieno „taikinio“ (angl. target) modulio TM1H (5 pav.) vamzdžio tyrimai taikant tekejjimo prieš suirimą metodiką. Vamzdžio vieta, kurioje buvo modeliuojamas kiauras plyšys, parinkta pagal ịtempių būvio analizę. Uždaviniui atlikti buvo sudarytas šio modulio baigtinių elementų modelis, atlikta ittempių analizė (19a pav.) ir nustatyta labiausiai apkrauta nagrinejjamos konstrukcijos vieta.

Taikant R6 metodiką apskaičiuoti priimtini ir kritiniai plyšių dydžiai parinktame vamzdyje (19b pav.). Naudojant kompiuterinès baigtinių elementų programą CAST3 paruoštas vamzdžio su kiauru plyšiu baigtinių elementų modelis ir apskaičiuotas plyšio atsiverrimo dydis (20 pav.).

Naudojantis kompiuterine programa SQUIRT v.2.4 buvo apskaičiuotas aušinimo skysčio ištekèjimas per kiaurą plyšị. Taip pat išnagrinèti galimi plyšio augimo greičiai veikiant senèjimo mechanizmams (ịtempinis korozinis pleišèjimas ir nuovargis veikiant magnetiniams laukams). Ivertinus aušinimo skysčio ištekèjimo per kiaurą plyši ir plyšio augimo greičius, buvo atlikta vamzdžio tekejimo prieš suirimą (TPS) analizè. Pagal TPS reikalavimus, postuluojamo kiauro plyšio ilgis, kuriam esant pasiekiamas nustatytas ištekejjimo greitis, turi būti dvigubai mažesnis už kritinio kiauro plyšio ilgị (viršijus kritinị ilgi vamzdis nutrūksta). Apskaičiuota, kad priimti-

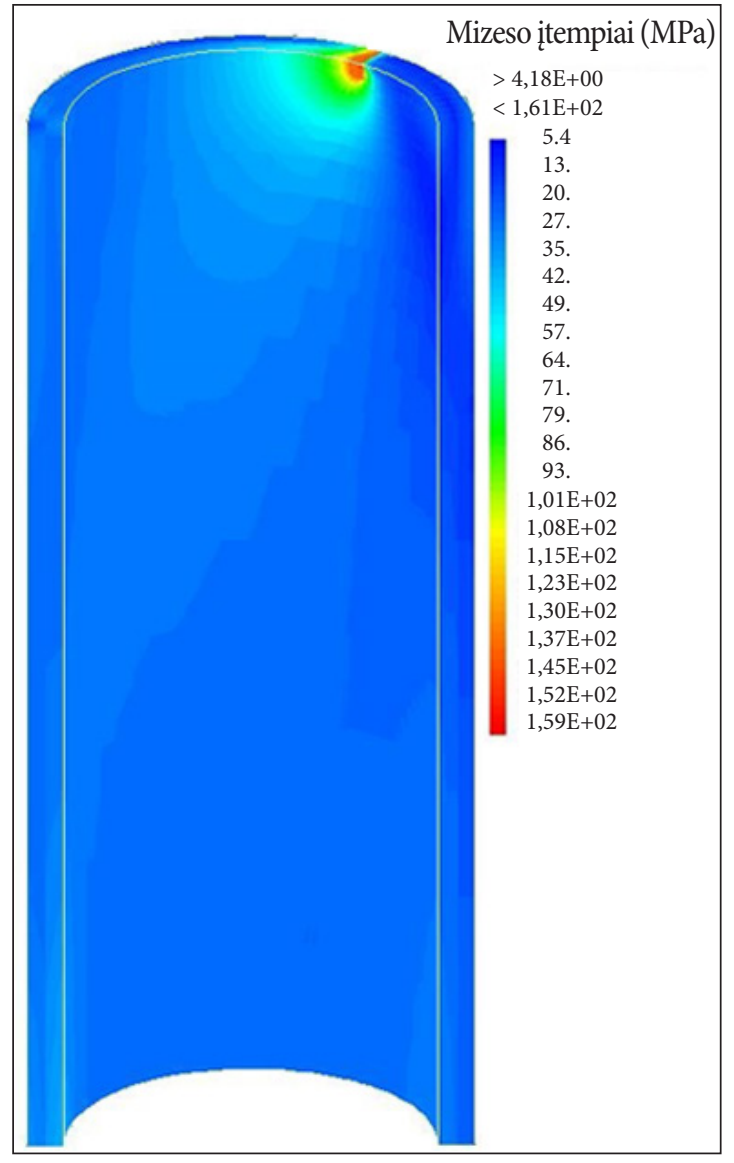

20 pav. Target modulio TM1H vamzdžio su kiauru plyšiu baigtinių elementų modelis ir j̇tempių pasiskirstymas

no kiauro plyšio ilgis $(1,4 \mathrm{~mm})$ yra daugiau nei keturis kartus mažesnis už kritinio kiauro plyšio ilgi $(6,5 \mathrm{~mm})$, o ištekančio vandens srautas per priimtiną kiaurą plyši yra $0,1 \mathrm{~kg} / \mathrm{val} .(\sim 0,03 \mathrm{~g} / \mathrm{s})$. Dèl ištekančio vandens užges plazma, o įrenginys bus saugiai sustabdytas.

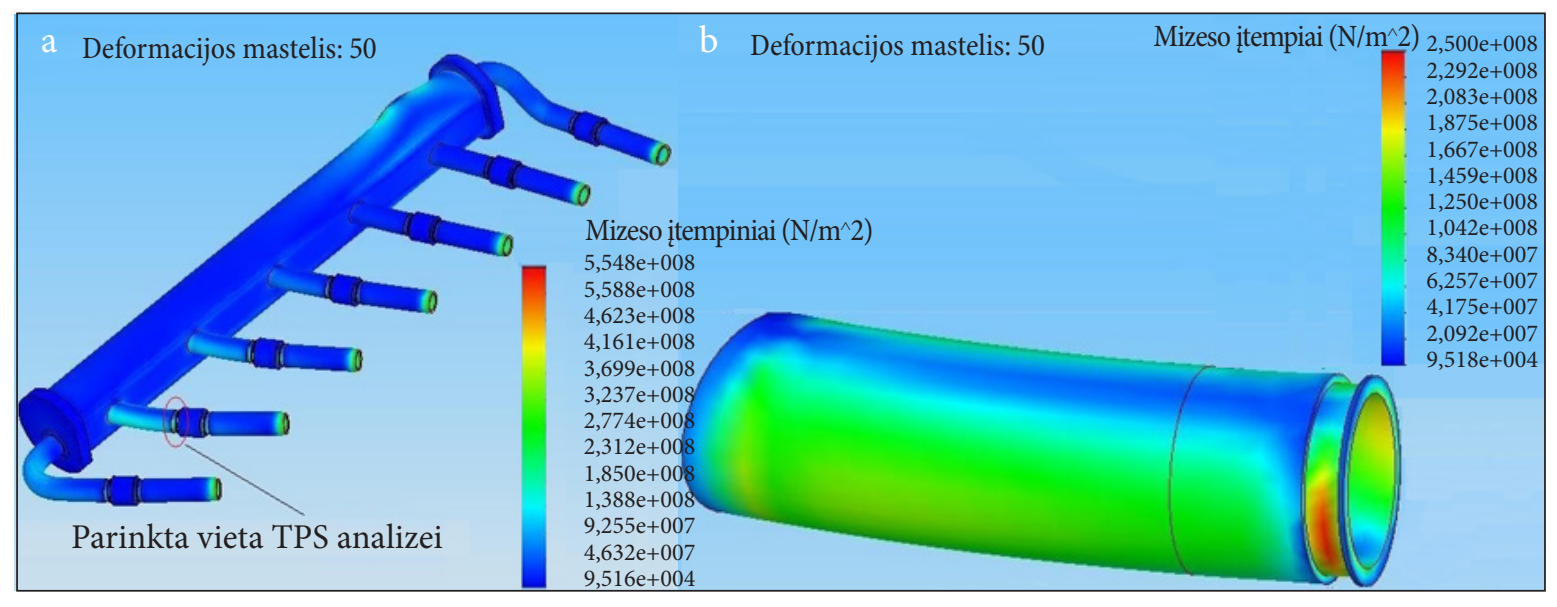

19 pav. Target modulio TM1H baigtinių elementų modelis ir apskaičiuotų jtempių pasiskirstymas 
Remiantis plyšio augimo greičio prognozès rezultatais galima teigti, kad nuovarginio plyšio augimas, veikiant magnetiniams laukams ir itempinei korozijai, nepasieks kritinio plyšio dydžių reaktoriaus stabdymo metu (21 pav.). Todèl divertoriaus modulis TM1H tenkina tekèjimo prieš suirimą reikalavimus.

\section{Plazmos indo angų suvirinimo siūlių struktūrinio vientisumo tyrimai}

W7-X įrenginio išorinis indas ir plazmos indas yra sujungti atvamzdžiais. Vertinant šio įrenginio struktūrinį vientisumą yra svarbu ịvertinti atvamzdžių suvirinimo siūlių stiprumą veikiant eksploatacinems apkrovoms ir nustatyti atsargos koeficientą. Projektuojant ypatingos svarbos inžinerines konstrukcijas ir vertinant jų saugumą dažniausiai taikomi ribinio būvio kriterijai. Vienas iš ribinio būvio kriterijų yra plastinis suirimas, o ši suirimą sukelianti apkrova vadinama ribine apkrova. Ribinei apkrovai nustatyti taikomi ribinès analizès analitiniai ir skaitiniai metodai. Atsižvelgiant $\mathfrak{i}$ tai, kad stelaratoriaus W7-X konstrukcija bei geometrija yra sudètinga, ribinei analizei atlikti buvo naudojama baigtinių elementų metodika. Kompiuterine programa ABAQUS sukurtas įrenginio W7-X sudètingos konfigūracijos angos baigtinių elementų modelis, apimantis atvamzdị, plazmos indo dali bei jų suvirinimo siūlę (22 pav.). Sumodeliuota anga - tai viena iš 254 W7-X įrenginio angų, jungiančių plazmos indą su išoriniu indu.

Paruošti angų geometriniai modeliai buvo perkelti ị baigtinių elementų kompiuterinę programą

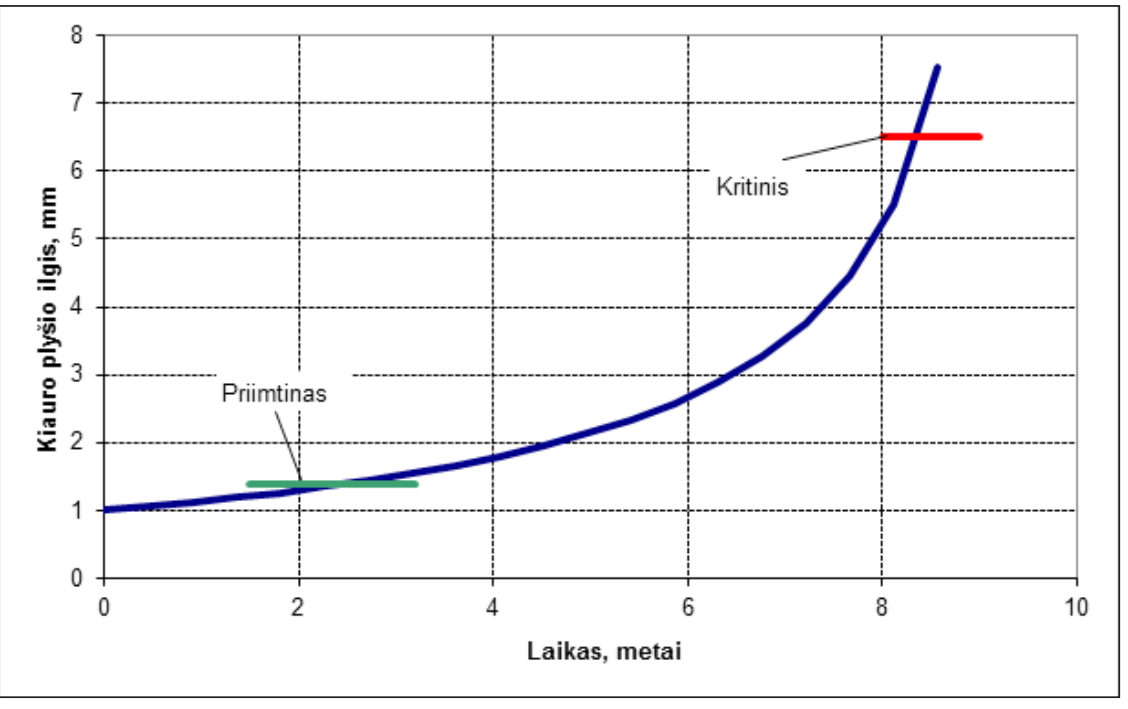

21 pav. Itempinės korozijos kiauro plyšio augimas priklausomai nuo reaktoriaus eksploatacijos laiko

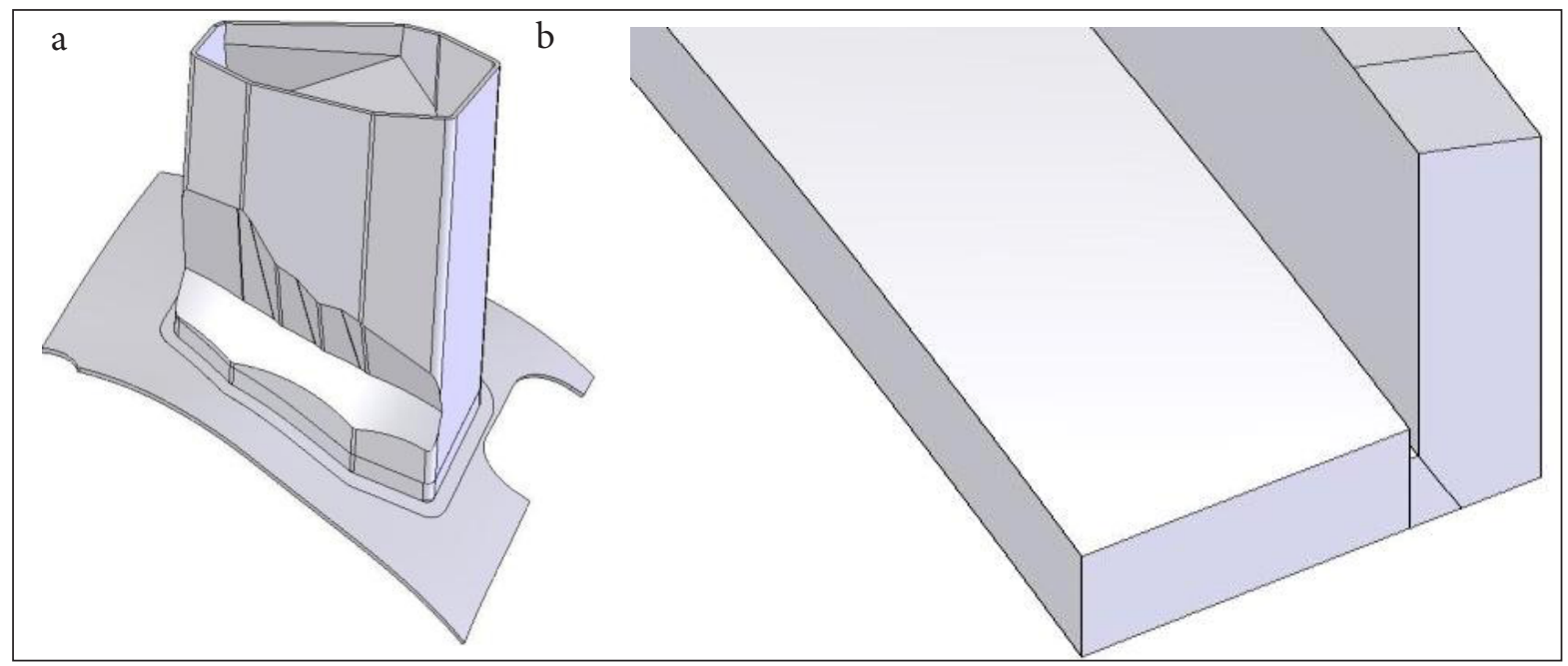

22 pav. Plazmos indo angos suvirinimo siūlès geometrinis modelis: a) geometrinis modelis, b) suvirinimo siūlès padidintas vaizdas 
ABAQUS/Standard, kuria parengtas plazmos indo angos suvirinimo siūlès baigtinių elementų modelis (23a pav.). Gauti poslinkiu pasiskirstymai plazmos indo angoje pateikti 23b pav.

Atliekant ribinę analizę skaitinị modelị veikiančios jègos buvo padaugintos iš mastelinio koeficiento (SF), kurị didinant nustatomas angos poslinkis jègų ir momento pridejjimo taške. Tuo atveju, kai angos poslinkiai pradeda staigiai didèti arba uždavinys nekonverguoja, priimta, kad pasiektas konstrukcijos ribinis būvis ir veikianti apkrova yra ribinè. 24 pav. pavaizduota nagrinè- tos angos poslinkio priklausomybė nuo mastelinio koeficiento. Jègų ir momentų pridejjimo taško poslinkiai tiesiškai dideja iki $\mathrm{SF}=3,8$. Staigiau poslinkiai pradeda dideti, kai 3,8 $<\mathrm{SF} \leq 4,5$. Dar akivaizdesni pakitimai, kai SF $>4,5$. Baigtinių elementų uždavinys nekonverguoja, kai mastelinis koeficientas pasiekia 6 . Atsižvelgiant $\mathfrak{i}$ tai nustatyta, kad nagrinètos angos ribinè apkrova bus pasiekta, kai mastelinis koeficientas $\mathrm{SF}=6$. Paveiksle pavaizduotos skaičiavimo versijos $\mathrm{V} \_$, $\mathrm{V} \_2$ ir V_3 - tai angos ribinès analizès rezultatai naudojant skirtingus jègų pridejjimo žingsnius.

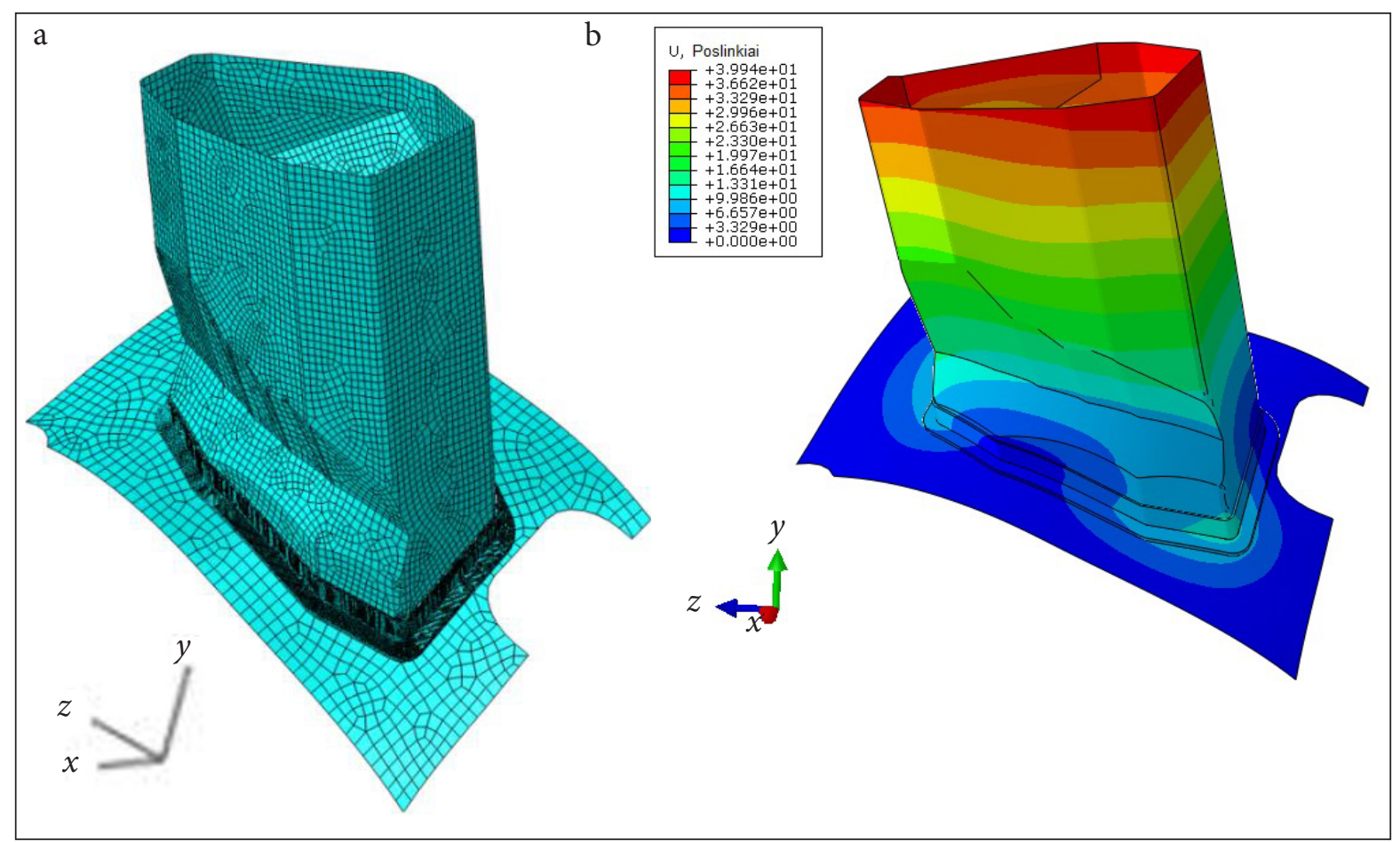

23 pav. Plazmos indo angos suvirinimo siūlès baigtinių elementų modelis (a) ir analizės rezultatai (b)

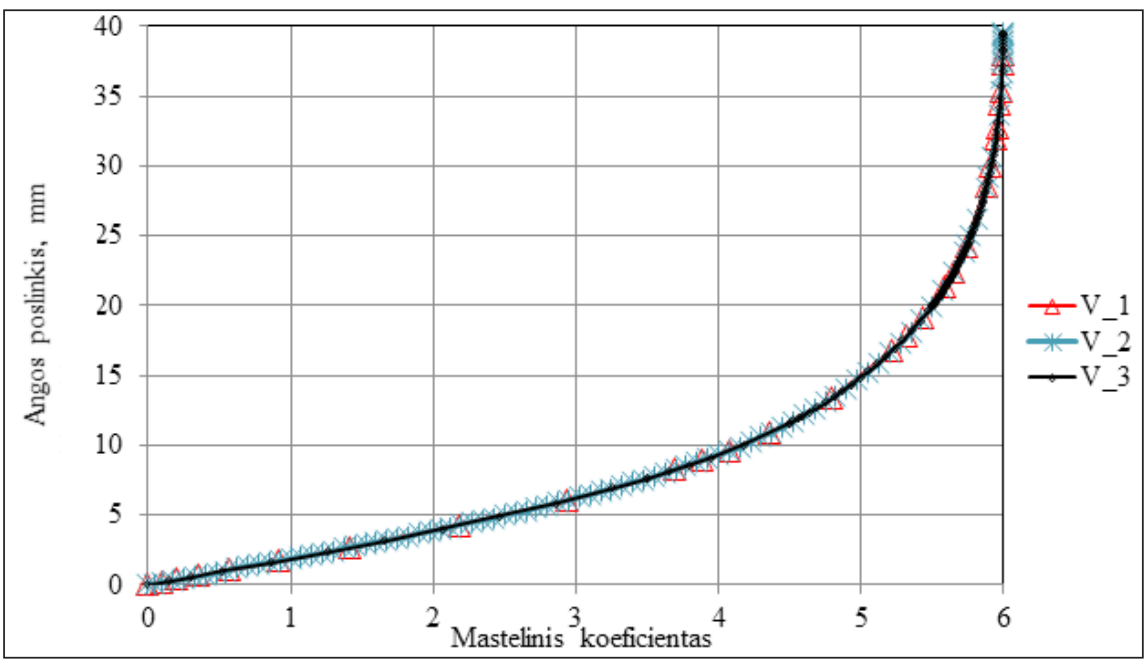

24 pav. Angos AEK20 poslinkių priklausomybė nuo mastelinio koeficiento 


\section{Duomenų analizè ir ịrangos patikimumo tyrimai}

Branduolių sintezès įrenginių patikimumo ir atskirų irangos komponentų bei sistemų gedimo duomenų analizè yra tarpusavyje susijusios temos. I atitinkamų klausimų sprendimą LEI BĮSL mokslininkai įsitrauke dar $2012 \mathrm{~m}$. vykdydami EFDA projektą. Nuo 2014 m., pradejus vykdyti EUROfusion projektą, darbai buvo pratęsti. Duomenų analizè daugiausia buvo siejama su atskirų sistemų darbo ir patikimumo parametrų vertinimu, parametrų reikšmingumo nustatymu bei ìvairių ịverčių neapibrèžtumo ir jautrumo analize. Patikimumo tyrimai buvo vykdomi susietai su RAMI (angl. Reliability, Availability, Maintainability, Inspectability - RAMI) analize ir jos bei tikimybinès saugos analizès (TSA) taikymu, kai nagrinejjama atskiru sistemų patikimumo parametrų itaka ịvairiems rizikos kitimo scenarijams, pačių sistemų patikimumo ir žmogaus klaidų vertinimu bei tikslumo analize.

\section{Duomenų ir patikimumo parametrų tyrimai}

Siekiant kuo tiksliau ịvertinti branduolių sintezès įrenginių (pvz., W7-X, DEMO, ITER) patikimumą, statistinès informacijos kiekis yra itin svarbus. Kuo daugiau duomenu yra prieinama, tuo tikslesnè analizè gali būti atlikta. Tačiau dauguma tokių ìrenginių yra ar dar tik bus pirmieji iš tokio tipo įrenginių, todèl didelei daliai jų sistemų yra labai mažai arba visai nèra statistinès informacijos apie jų sutrikimus ar gedimus.

Vienas iš galimų būdų siekiant užtikrinti tyrimų tikslumą - panaudoti branduolinèje pramoneje sukauptą informaciją apie panašių sistemų veikimą. Be to, ekspertų žinios taip pat neturètų būti ignoruojamos - netgi subjektyvūs vertinimai apie retai gendančias sistemas ir jų patikimumo parametrus (pvz., gedimų intensyvumą) turètų būti tiriami ir apjungiami kartu su statistiniais duomenimis (jei tokių apskritai esama). Šiems uždaviniams spręsti, visų pirma, buvo atlikta esamų patikimumo duomenų šaltinių, kurie galètų būti panaudojami minètų sistemų patikimumui vertinti, apžvalga. Tada, pasinaudojus subjektyvios tikimybès ypatybèmis bei Bajeso ir kt. metodais, buvo sudaryta ir pritaikyta metodika skirtingu tipų duomenų analizei ir parametrų ívertinimui atlikti. Informacijos apjungimo supaprastinta schema pateikta 25 pav.

Siekiant ịvertinti esamų patikimumo duomenų pritaikomumą branduolių sintezès įrenginiams buvo apžvelgti 5 pagrindiniai informacijos šaltiniai: FCFR (Fusion Component Failure Database), TATENA duomenu imtys, WASH (Reactor Safety Study: An Assessment of Accident Risks in U. S. Commercial Nuclear Power Plant) ataskaita, T-Book (Reliability Data of Components in Nordic Nuclear Power Plants) bei duomenys, prieinami per programinę priemonę Lambda-Predict. Galima pažymèti, kad įvairiuose informacijos šaltiniuose duomenų irašai dažnai yra neišbaigti, jiems registruoti taikomi skirtingo pobūdžio kriterijai ir prielaidos.

Minèta metodika buvo pritaikyta DEMO reaktoriaus su HCLL tipo apvalkalu pagrindinès aušinimo sistemos vamzdynų tyrimams. Bendras nagrinètu vamzdynų ilgis apytikriai siekè $3840 \mathrm{~m}$. Dèl informacijos trūkumo vamzdynų gedimų pobūdis nebuvo klasifikuojamas. Duomenų bazèse analogiškiems vamzdynams buvo tik 9 gedimų dažnio įverčiai. Kai kurie ịrašai buvo su kvantilių reikšmèmis. Klasikinè statistiné analizè tokios

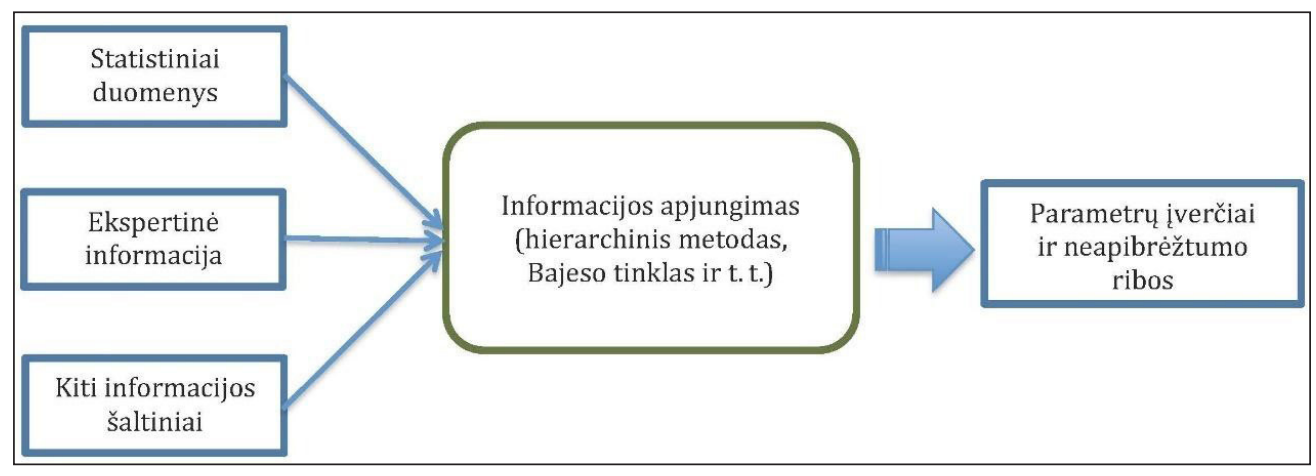

25 pav. Parametrams jivertinti naudojamos informacijos apjungimas 
papildomos informacijos ịtraukti neturi galimybių, tačiau minèta metodika leido panaudoti ir šiuos dydžius.

Papildoma informacija apie kvantilių ịverčius buvo pasinaudota tik pritaikius metodikos dali, skirtą ekspertų vertinimams ittraukti. Taigi, gali būti laikoma, kad kvantiliai yra pateikti ekspertų ir iš šios informacijos suformuojamas apriorinis skirstinys, kuris apjungiamas kartu su gedimų intensyvumo vidurkio ịverčiais. Taip gaunamas tikslesnis aposteriorinis skirstinys, nusakantis atnaujintą gedimų intensyvumo įverčio reikšmę.

Gauti atnaujinti ịverčiai, ịtraukus ekspertinę informaciją, buvo lyginami su klasikinès statistikos procedūromis gautais ịverčiais. Pastebèta, kad sukurta metodika sudarè galimybę papildomą informaciją apie kvantilius ịtraukti ị bendrą vertinimą, o tai turèjo įtakos ịverčiams (žr. 1 lentelę). Pateikti duomenys atskleidžia, kaip ịtraukiant skirtingų tipų informaciją į DEMO sistemų analizę galima atnaujinti ịverčius ir sumažinti neapibrèžtumą.

\section{1 lentelè. Aušinimo sistemos vamzdynų gedimo tikimybė}

\begin{tabular}{|c|c|c|c|c|}
\hline & Vidurkis & $\begin{array}{c}0,05 \\
\text { kvantilis }\end{array}$ & $\begin{array}{c}0,95 \\
\text { kvantilis }\end{array}$ & \\
\hline \multirow{2}{*}{ ڤ્ટ } & $1,85 \mathrm{E}-05$ & $2,00 \mathrm{E}-09$ & $7,90 \mathrm{E}-05$ & $\begin{array}{l}\text { Be ekspertų } \\
\text { informacijos }\end{array}$ \\
\hline & $7,70 \mathrm{E}-06$ & $9,90 \mathrm{E}-09$ & $2,70 \mathrm{E}-05$ & $\begin{array}{l}\text { Itraukus ekspertų } \\
\text { informaciją }\end{array}$ \\
\hline
\end{tabular}

\section{Parametrų reikšmingumo ir rezultatų jautrumo analizè}

Pastaraisiais metais apibendrinti ankstesni tyrimai, susiję tiek su RAMI, tiek ir su reikšmingumo bei jautrumo analizès taikymu branduolių sintezès ịrenginiams. Kaip pavyzdị galima paminèti W7-X sistemų / įrangos analizę.
Siekiant didinti ịvairių sistemų parengtumą reikia nustatyti jų silpnąsias vietas, pasiūlyti ir išrinkti gerinimo priemones. Pilotiniam tyrimui parinktas divertoriaus aušinimo kontūras (DAK). DAK sudaro du šilumokaičiai, du siurbliai, kolektorius ir vamzdžiai, kurie tiekia šaltą vandeni i t plazmos indo ir skirtingų atvamzdžių aušinimo vamzdelius bei nuveda šiltą vandenị atgal ị šilumokaičius. Priklausomai nuo W7-X darbo režimo turi veikti vienas (laukimo režimas arba dalinė apkrova) arba abu (normali arba pilna apkrova) siurbliai.

DAK apskaičiuotas vidutinis neparengtumas per metus siekia 0,188 . Septyni pagrindiniai gedimai, turintys didžiausios țtakos DAK neparengtumui, pateikti 2 lenteleje. Likusiụjų gedimų indèlis yra tik $0,01 \%$ ị bendrą DAK neparengtumą.

Atlikus analizę tapo akivaizdu, kad didžiausios itakos DAK neparengtumui turi antrojo, dukart per dieną jungiamo siurblio, taip pat jo sklendès bei atbulinio vožtuvo gedimai. DAK patikimumo parametrų reikšmingumo ir jautrumo analizès rezultatai rodo, kad didžiausios itakos DAK neparengtumui turi ilgas remonto laikas - vienas mènuo. Gauti rezultatai leidžia nustatyti DAK parengtumo didinimo priemoniu prioritetus. Rezultatai rodo, kad siekiant padidinti DAK parengtumą reikia mažinti siurblio atstatymo (remonto) laiką arba didinti susijusių komponentų patikimumą.

Dalyvaujant DEMO elektrinès ir kt. įrenginių analizès veikloje taip pat buvo rengta neapibrèžtumo analizès ir susijusio rezultatų jautrumo analizės bendresné metodika. Jautrumo analizeje dažnai buvo naudojami ne tik santykiniai, bet ir tokie jautrumo rodikliai kaip standartiniai regresijos koeficientai bei koreliacijos koeficientai, kurie leidžia klasifikuoti parametrų neapibrežtumo ittaką modeliavimo rezultatams.

2 lentelè. DTAK neparengtumo ir reikšmingumo / jautrumo analizės rezultatai

\begin{tabular}{c|c|c|c|c|c}
\hline Nr. & Ivykio aprašymas & $\begin{array}{c}\text { Neparengtumo } \\
\text { tikimybė }\end{array}$ & $\begin{array}{c}\text { Indèlis i DTAK } \\
\text { neparengtumą, \% }\end{array}$ & $\begin{array}{c}\text { Reikšmingumas } \\
\text { (Fussel-Vesely) }\end{array}$ & $\begin{array}{c}\text { Santykinis } \\
\text { jautrumas }\end{array}$ \\
\hline 1. & Siurblys AP002 nepasileidžia & $9,57 \mathrm{E}-02$ & 51 & $5,10 \mathrm{E}-01$ & $8,71 \mathrm{E}+00$ \\
\hline 2. & Sklendè KA510 neatsiveria & $6,60 \mathrm{E}-02$ & 35,1 & $3,51 \mathrm{E}-01$ & $5,17 \mathrm{E}+00$ \\
\hline 3. & Siurblys AP003 sustoja & $2,11 \mathrm{E}-02$ & 11,3 & $1,13 \mathrm{E}-01$ & $2,01 \mathrm{E}+00$ \\
\hline 4. & Šilumokaičio AD002 gedimas & $6,44 \mathrm{E}-03$ & 3,43 & $3,43 \mathrm{E}-02$ & $1,28 \mathrm{E}+00$ \\
\hline 5. & Šilumokaičio AD001 gedimas & $6,44 \mathrm{E}-03$ & 3,43 & $3,43 \mathrm{E}-02$ & $1,28 \mathrm{E}+00$ \\
\hline 6. & Vožtuvas KA507 neatsiveria & $3,52 \mathrm{E}-03$ & 1,87 & $1,87 \mathrm{E}-02$ & $1,15 \mathrm{E}+00$ \\
\hline 7. & Siurblys AP002 sustoja & $4,50 \mathrm{E}-04$ & 0,24 & $2,40 \mathrm{E}-03$ & $1,02 \mathrm{E}+00$ \\
\hline
\end{tabular}




\section{Parametrų itakos rizikos kitimo scenarijams analizè}

Pastaraisiais metais taip pat buvo apibendrinti anksčiau vykdyti tyrimai ir susijusi metodika, kuri sietina su TSA išplètojimu pritaikant ją branduolių sintezès įrenginių saugos bei patikimumo didinimui, atsižvelgiant tiek ị irangos, tiek $\mathfrak{i}$ personalo patikimumą. Atskirų parametrų ittaka bei jų reikšmingumas buvo nagrinètas taikant tikimybinès saugos analizès reikšmingumo rodiklius bei atskirų sistemų nesuveikimo scenarijų vertinimą. Dalis su minètais tyrimais susijusių metodų ir jų taikymo rezultatų buvo gauti tikimybinès saugos analizės bei kitų darbų, îvykdytų Ignalinos AE bei W7-X, analizès metu.

Eksperimentiniam stelaratoriui W7-X atlikta pilotinè avarijos dèl išorinio elektros tiekimo praradimo analize leidžia teigti, kad W7-X plazmos indo pažeidimo dèl galimo šilumnešio atšalimo dažnis yra $1,95 \cdot 10^{-3}$ per metus, o didžiausios itakos saugai turi elektros tinklo patikimumas, dyzelinio elektros generatoriaus patikimumas ir personalo veiksmai ijungiant (esant reikalui) alternatyvią elektros tiekimo liniją. Be to, išorinio tinklo praradimo atvejų rezervinio dyzelinio generatoriaus įrengimas labiau sumažintų riziką (72\%) nei personalo apmokymas veikti avarineje situacijoje (36\%), tačiau lěšų panaudojimo efektyvumas būtų mažesnis pirmuoju (7\%) nei antruoju (35\%) atveju.

Atliekant analizę buvo apskaičiuotas rizikos (kaštų) sumažejimas $\Delta \mathrm{K}$ ir ịvertintos rizikos mažinimo scenarijų išlaidos $C_{T}$ bei rizikos sumažèjimo ir išlaidų santykis kiekvienu variantu (3 lentelè). Trečiojo siurblio įrengimo ir atsarginių dalių pirkimo variantai pasižymi panašiomis rizikos sumažèjimo reikšmèmis, tačiau atsarginių dalių pirkimo išlaidų efektyvumo koeficientas yra didesnis - 3,1, o ne 1,8 . Taigi, DTAK atsarginių dalių rezervavimas siekiant sumažinti remonto laiką pasižymi

3 Ientelè. Išlaidų efektyvumas DTAK rizikos sumažinimo variantams

\begin{tabular}{|c|c|c|c|}
\hline Variantas & 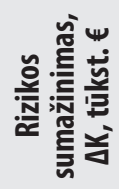 & 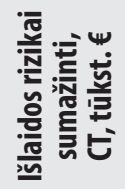 & 롤를 \\
\hline Trečiojo siurblio įrengimas & 387,8 & 220,0 & 1,8 \\
\hline Atsarginių dalių pirkimas & 359,5 & 115,0 & 3,1 \\
\hline Techninis aptarnavimas & 82,6 & 42,7 & 1,9 \\
\hline
\end{tabular}

didžiausiu kaštų efektyvumu (3,1), palyginti su rezervinio siurblio įrengimu $(1,8)$ ir profilaktiniu aptarnavimu $(1,9)$.

Apibendrinant branduolių sintezès įrenginiams skirtus rizikos vertinimus buvo pasiūlyti modifikuoti tikimybinès saugos analizès tikslai, kai siekiama integruoto sistemų neparengtumo vertinimo bei avarijų, sukeliančių plazmos indo irangos pažeidimus, analizės. Kaip alternatyva iprastiems RAMI tyrimams, kurie labiau orientuoti ị sistemų funkcijas, negu ị jas sudarančius komponentus, W7-X irrenginiui sistemų lygiu pirmą kartą buvo atlikta tikimybinè saugos analizè ir jos taikymas nustatant rizikos vertinimu pagrịstus sprendimus.

\section{Technologijų patikimumo vertinimas ir jo tikslumo analizè}

DEMO turbinu patikimumo vertinimas atliktas atsižvelgiant ị pulsuojantị turbinų veikimo režimą. Sukurta metodika DEMO elektrinès sistemų patikimumui vertinti panaudojant Bajesinius tinklus. Iprastai taikomas kitas šios sistemos patikimumo vertinimo būdas naudoja vien tik tos sistemos gedimų medžius. Tačiau šis būdas neleidžia išsamiau atsižvelgti ị gedimų duomenų neapibrèžtumą.

Pasiūlytos metodikos pagrindas yra gedimų medžių konvertavimas į Bajesinius tinklus, ịtraukiant neapibrežtumą ir taip gaunant išsamesnị sistemos patikimumo vertinimą. Kartu su partneriais iš ENEA (Italija) organizacijos atlikta parengtumo analizè parode, kad varijuojant turbinos komponentų gedimų intensyvumus parengtumas (20 metų laikotarpiui) šiek tiek keičiasi intervale nuo 79 iki $82 \%$. Atlikus jautrumo analizę nustatyta, kad garo kokybès sistemos gedimui didžiausios įtakos turi kondensato surinkimo posistemè (angl. condensate trap).

Siekiant patobulinti DEMO reaktoriaus patikimumo vertinimo priemones ir jų pritaikomumą heliu aušinamo DEMO reaktoriaus koncepcijos patikimumui vertinti, ankstesnè metodika buvo papildyta įtraukiant gedimų intensyvumo korekcijos daugiklius. Kadangi su DEMO reaktoriaus sistemomis susijusių patikimumo duomenų yra labai mažai (kai kurioms sistemoms tokių duomenų visiškai nèra), tai paprastai yra naudojami branduolinių (ar kito tipo) elektrinių sistemų gedimų duomenys. Tačiau sąlygos, 
kuriomis veiks DEMO sistemos, nèra identiškos sąlygoms branduolinèse (ar kito tipo) elektrinèse.

Pavyzdžiui, jei DEMO aušinimo sistemoje būtų naudojamas helis, tai jo poveikis vamzdynams būtų kitoks nei naudojant vandenị. Helis yra inertiškas, o dèl šios priežasties vamzdynai nebūtų veikiami korozijos. Metodika buvo pritaikyta heliu aušinamo DEMO reaktoriaus pagrindinès aušinimo sistemos vamzdynams. Nustatyta, kad šios sistemos atveju branduolinès elektrinès duomenys pakankami tiksliai įvertina vamzdynų patikimumą, kadangi korekcijos daugiklio įtaka (26 pav.) gedimo tikimybei yra nereikšminga.

\section{Žmogaus klaidos tikimybès ir patikimumo iverčio patikslinimas}

Susietai su vykdyta avarijų ir duomenų analize sudarius žmogaus klaidos tikimybę vertinančius modelius, buvo išplètoti su branduolinès ir termobranduolinès įrangos sauga ir valdymu susiję aktualūs skaičiavimai, atliktas ịrangos gedimų bei žmogaus klaidų vertinimo metodikos apibendrinimas. Iš pradžių buvo atlikta žmogaus patikimumo ịvertinimo metodų ir jų taikymo apžvalga. Po to, tęsiant ir atnaujinant atskiros branduolių sintezès įrenginio sistemos testavimo ir jo optimizavimo tyrimą, atliktas galimų žmogaus klaidų vertinimas ir taip buvo patikslintas sistemos techninès priežiūros optimizavimo modelis. Be to, šiame etape buvo išplètota ir apibendrinta tradiciškai branduolinèje energetikoje taikoma tikimybinè saugos analizè bei patikimumo tyrimai, išplečiant jų pritaikymą branduolių sintezès įrenginiams.
Papildomas dèmesys buvo nukreiptas ị žmogiškųjų faktorių vertinimą, kai atsižvelgiant $\mathfrak{i}$ operatorių veiksmus ir galimas klaidas buvo siekiama sumodeliuoti realistišką sistemos funkcionavimą bei adekvačius avarijų valdymo scenarijus. Tokie modeliavimai lemia mažiau konservatyvias ir mažiau neapibrèžtas prielaidas bei leidžia patikslinti patikimumo vertinimo rezultatus tiek anksčiau vertintos Ignalinos $\mathrm{AE}$ (pvz., avarinių aktyviosios zonos aušinimo siurblių) atveju, tiek ir nagrinèto branduolių sintezès įrenginio W7-X atveju. Šiame etape atlikti tyrimai leidžia nustatyti optimalų testavimo ir remonto periodiškumą, kai yra minimizuojamas nagrinejjamos sistemos neparengtumas atlikti jai numatytas funkcijas. Tokia analizè leidžia kiekybiškai ịvertinti gedimų ir klaidų ịtaką galutiniam avarijos dažniui ir nustatyti saugos gerinimo prioritetus siekiant sumažinti neigiamų pasekmių tikimybę.

Be to, sudarant metodiką, leidžiančią apjungti ivvairių tipų informaciją ir patikslinti naujų sistemų (pvz., DEMO) patikimumo parametrų ivverčius, kaip minèta, buvo pasinaudota Bajeso metodais. Bajeso metodai suteikia galimybę analizuoti labai ivvairią informaciją vienu metu, ar tai būtų subjektyvi žmogaus nuomoné, ar statistinių duomenų imtis, surinkta per tam tikrą laikotarpị, ar įrašai duomenų bazèse. Kai atsiranda nauji duomenys ar informacija, nèra reikalo visą analizę atlikti nuo pradžių, kadangi Bajeso metodai suteikia galimybę atnaujinti jau esamus ịverčius su nauja informacija - senieji ịverčiai panaudojami kaip apriorinè informacija, kuri apjungiama su naujais duomenimis ir gaunamas aposteriorinis skirstinys.

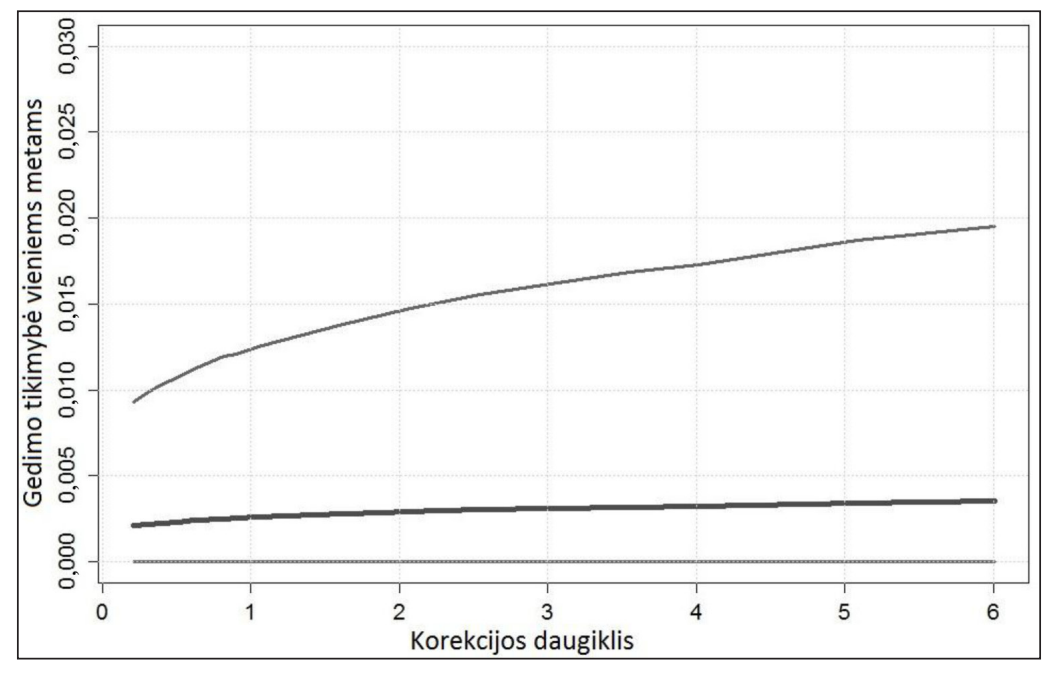

26 pav. Heliu aušinamo reaktoriaus vamzdynų gedimo tikimybės priklausomybė nuo korekcijos daugiklio 
Viena sudarytos metodikos dalis buvo skirta ekspertų subjektyviems įverčiams analizuoti. Šios metodikos žingsniai lakoniškai gali būti apibendrinti taip (praleidžiant sudetingas matematines formuluotes):

- sudaryti grupę iš kiek galima daugiau srities ekspertų ir paprašyti pateikti informaciją apie kvantilius ir parametrų tikimybes;

- pasirinkti funkcinę apriorinio skirstinio formą atsižvelgiant ị problemos pobūdị (beta, gama, normalujji ir t. t.);

- panaudojus Bajeso tikimybès atnaujinimo formules, apskaičiuoti ekspertų subjektyvių îverčių skirstinit;

- panaudoti gautą skirstinị kaip apriorinį, jei yra papildomos informacijos, pavyzdžiui, statistinių duomenų, ir apskaičiuoti aposteriorini skirstinį, išreiškiantị visą prieinamą tikimybinę informaciją apie nagrinejjamos sistemos ar komponento patikimumą.

\section{APIBENDRINIMAS IR IŠVADOS}

Lietuvos energetikos instituto Branduolinių įrenginių saugos laboratorijos mokslininkai pradejo tyrimus branduolių sintezès tyrimų srityje dar $2006 \mathrm{~m}$. ir šiuose tyrimuose sèkmingai pritaiko iki to laiko sukauptą patirtị vykdant branduolinių elektrinių saugos tyrimus.

Branduolių sintezès tyrimai yra labai aktyviai vykdomi visame pasaulyje: šiais metais Vokietijoje, Greifsvalde, pradetas eksploatuoti stelaratoriaus tipo irenginys Wendelstein 7-X, o Prancūzijoje, Cadarache, statomas didžiausias eksperimentinis įrenginys ITER. Vykdant W 7-X irenginio saugos pagrindimo ir struktūrinio vientisumo vertinimo darbus aktyviai dalyvavo LEI BItSL mokslininkai.

Šiuo metu vyksta demonstracinio branduolių sintezès reaktoriaus DEMO projektavimas, tad būtina užtikrinti, kad saugos klausimai būtų îvertinti jau šiame etape, būtų užtikrintas šio ịrenginio saugumas. LEI BĮSL mokslininkai aktyviai prisideda prie DEMO reaktoriaus saugos vertinimo.

Lietuvos energetikos instituto Branduolinių įrenginių saugos laboratorijos mokslininkai igavo patirties ir vykdo branduoliu sintezès irenginiu saugos vertinimą, struktūrinę ir stipruminę analizę, įrangos patikimumo tyrimus ir neutronų pernašos tyrimus.
LEI BĮSL mokslininkų intensyviai atliekamų branduolių sintezès reaktoriuose DD ir DT reakcijų metu susidarančių neutronų, jų sąveikos su medžiagomis ir sukelto aktyvumo bei dalijimosi šilumos ir dozés galios procesų tyrimų duomenys yra ir bus aktualūs eksploatuojant ir projektuojant europinius branduolių sintezès įrenginius JET, ITER ir DEMO.

Gauta 20160630 Priimta 20160830

Pagrindinès branduolių sintezès tyrimų tematika paskelbtos publikacijos

1. Kaliatka T., Kaliatka A., Kačegavičius T., Naujoks D. Analysis of the processes in the target cooling system of the W7-X fusion experiment. Kerntechnik. 2010. Vol. 75. No. 5. P. 255-262.

2. Kaliatka A., Povilaitis M., Urbonavičius E., Kaliatka T. Analysis of the consequences of targets feeding pipe rupture in Wendelstein 7-X experimental nuclear fusion device. The 8th International Topical Meeting on Nuclear Thermal-Hydraulics, Operation and Safety (NUTHOS-8), October 10-14, 2010, Shanghai Jiao Tong University, Shanghai, China. P. 1-12.

3. Kaliatka A., Ušpuras E., Kaliatka T. Pressure surge in Wendelstein 7-X experimental stellarator facility. The 14th International Topical Meeting on Nuclear Reactor Thermal Hydraulics (NURETH-14), September 25-30, 2011, Toronto, Ontario, Canada. P. 1-14.

4. Kaliatka A., Ušpuras E., Kaliatka T. Analysis of thermal hydraulic processes in Wendelstein 7-X experimental nuclear fusion facility. Proceedings of International Congress on Advances in Nuclear Power Plants (ICAPP 2011), May 2-5, 2011, Nice, France. P. 1996-2004.

5. Kaliatka A., Ušpuras E. Kaliatka T. Pressure surge in Wendelstein 7-X experimental stellarator facility. Kerntechnik. 2012. Vol. 77. No. 2. P. 134-140.

6. Kaliatka T., Povilaitis M., Kaliatka A., Urbonavičius E. Simulation of targets feeding pipe rupture in Wendelstein 7-X facility using RELAP5 and COCOSYS codes. Journal of Fusion Energy. 2012. Vol. 31. No. 5. P. 506-517.

7. Ušpuras E., Kaliatka A., Kaliatka T. Analysis of the accident with the coolant discharge into the plasma vessel of the W7-X fusion experimental 
facility. Fusion Engineering and Design. 2013. Vol. 88. Iss. 5. P. 304-310.

8. Dundulis G., Janulionis R., Karalevičius R. The application of leak before break concept to W7-X target module. Fusion Engineering and Design. 2013. Vol. 88. P. 307-313.

9. Kaliatka T., Ušpuras E., Kaliatka A. Analysis of processes in vacuum vessel during ingress of coolant event. The 15th International Topical Meeting on Nuclear Reactor Thermal Hydraulics (NURETH-15), May 12-17, 2013, Pisa, Italy (CD). P. 1-8.

10. Stankūnas G. Experimental study of p $(1 \mathrm{GeV})+$ natU fission-spallation reaction and delayed neutron measurements. International Journal of Modern Physics E Nuclear Physics. ISSN 02183013. 2013. Vol. 22. Iss. 12. P. 1-12.

11. Stankunas G., Syme B., Popovichev S., Conroy S., Batistoni P. Safety analyses in support of neutron detector calibration operations. The 11th International Symposium on Fusion Nuclear Technology, September 16-20, 2013, Barcelona.

12. Voronov R., Alzbutas R. Probabilistic reliability and risk analysis for systems of fusion device. Proceedings of the 20th Advances in Risk and Reliability Technology Symposium (AR2TS), May 21-23, 2013, Loughborough University, Loughborough, Leicestershire, ISBN 978-1-907382611. P. 347-355.

13. Voronov R., Alzbutas R. Application of probabilistic safety and reliability analysis for a system of fusion facility. Energetika. 2013. T. 59. Nr. 4. P. 183-193.

14. Bosch H.-S., Wolf R. C., Andreeva T., Baldzuhn J., Birus D., Bluhm T., Bräuer T., Braune H., Bykov V., Cardella A., Durodié F., Endler M., Erckmann V., Gantenbein G., Hartmann D., Hathiramani D., Heimann P., Heinemann B., Hennig C., Hirsch M., Holtum D., Jagielski J., Jelonnek J., Kasparek W., Klinger T., König R., Kornejew P., Kroiss H., Krom J. G., Kühner G., Laqua H., Laqua H. P., Lechte C., Lewerentz M., Maier J., McNeely P., Messiaen A., Michel G., Ongena J., Peacock A., Pedersen T. S., Riedl R., Riemann H., Rong P., Rust N., Schacht J., Schauer F., Schroeder R., Schweer B., Spring A., Stäbler A., Thumm M., Turkin Y., Wegener L., Werne A., Zhang D., Zilker M., Akijama T., Alzbutas R., Ascasibar E., Balden M., Banduch M., Baylard Ch., Behr W., Beidler C., Benndorf A., Bergmann T., Biedermann C., Bieg B., Biel W.,
Borchardt M., Borowitz G., Borsuk V., Bozhenkov S., Brakel R., Brand H., Brown T., Brucker B., Burhenn R., Buscher K-P., Caldwell-Nichols C., Cappa A., Cardella A., Carls A., Carvalho P., Ciupiński Ł., Cole M., Collienne J., Czarnecka A., Czymek G., Dammertz G., Dhard C. P., Davydenko V. I., Dinklage A., Drevlak M., Drotziger S., Dudek A., Dumortier P., Dundulis G., Eeten P. V., Egorov K., Estrada T., Faugel H., Fellinger J., Feng Y., Fernandes H., Fietz W. H., Figacz W., Fischer F., Fontdecaba J., Freund A., Funaba T., Fünfgelder H., Galkowski A., Gates D., Giannone L., García Regaña J. M., Geiger J., Geißler S., Greuner H., Grahl M., Groß S., Grosman A., Grote H., Grulke O., Haas M., Haiduk L., Hartfuß H. J., Harris J. H., Haus D., Hein B., Heitzenroeder P., Helander P., Heller R., Hidalgo C., Hildebrandt D., Höhnle H., Holtz A., Holzhauer E., Holzthüm R., Huber A., Hunger H., Hurd F., Ihrke M., Illy S., Ivanov A., Jablonski S., Jaksic N., Jakubowski M., Jaspers R., Jensen H., Jenzsch H., Kacmarczyk J., Kaliatka T., Kallmeye J., Kamionka U., Karalevičius R., Kern S., Keunecke M., Kleiber R., Knauer J., Koch R., Kocsis G., Könies A., Köppen M., Koslowski R., Koshurinov J., Krämer-Flecken A., Krampitz R., Kravtsov Y., Krychowiak M., Krzesinski G., Ksiazek I., Kubkowska M., Kus A., Langish S., Laube R., Laux M., Lazerson S., Lennartz M., Li C., Lietzow R., Lohs A., Lorenz A., Louche F., Lubyako L., Lumsdaine A., Lyssoivan A., Maaßberg H., Marek P., Martens C., Marushchenko N., Mayer M., Mendelevitch B., Mertens Ph., Mikkelsen D., Mishchenko A., Missal B., Mizuuchi T., Modrow H., Mönnich T., Morizaki T., Murakami S., Musielok F., Nagel M., Naujoks D., Neilson H., Neubauer O., Neuner U., Nocentini R., Noterdaeme J.-M., Nührenberg C., Obermayer S., Offermanns G., Oosterbeek H., Otte M., Panin A., Pap M., Paquay S., Pasch E., Peng X., Petrov S., Pilopp D., Pirsch H., Plaum B., Pompon F., Povilaitis M., Preinhaelte J., Prinz O., Purps F., Rajna T., Récse S., Reiman A., Reiter D., Remmel J., Renard S., Rhode V., Riemann J., Rimkevičius S., Riße K., Rodatos A., Rodin I., Romé M., Roscher H.-J., Rummel K., Rummel Th., Runov A., Ryc L., Sachtleben J., Samartsev A., Sanchez M., Sano F., Scarabosio A., Schmid M., Schmitz H., Schmitz O., Schneider M., Schneider W., Scheibl L., Scholz M., Schröder G., Schröder M., Schruff J., Schumacher H., Shikhovtsev I. V., Shoj M., Siegl G., Skodzik J., Smirnow M., 
Speth E., Spong D. A., Stadle R., Sulek Z., Szabó V., Szabolics T., Szetefi T., Szökefalvi-Nagy Z., Tereshchenko A., Thomsen H., Thumm M., Timmermann D., Tittes H., To K., Tournianski M., Toussaint U., Tretter J., Tulipán S., Turba P., Uhlemann R., Urban J., Urbonavičius E., Urlings P., Valet S., Van Eester D., M. Van Schoor M., Vervier M., Viebke H., Vilbrandt R., Vrancken M., Wauters T., Weissgerber M., Weiß E., Weller A., Wendorf J., Wenzel U., Windisch T., Winkler E., Winkler M., Wolowski J., Wolters J., Wrochna G., Xanthopoulos P., Yamada H., Yokoyama M., Zacharias D., Zajac J., Zangl G., Zarnstorf M., Zeplien H., Zoletnik S., Zuin M. Technical challenges in the construction of steady-state stellarator Wendelstein 7-X. Nuclear Fusion. 2013. Vol. 53. No. 12. P. 1-16.

15. Kaliatka T., Ušpuras E., Kaliatka A. Modeling of water ingress in to vacuum vessel. Proceedings of the 22nd International Conference on Nuclear Engineering ICONE22, July 7-11, 2014, Prague, Czech Republic. P. 6.

16. Stankūnas G., Syme D. B., Popovichev S., Conroy S., Batistoni P. Safety analyses in support of neutron detector calibration operations at JET. Fusion Engineering and Design. 2014. Vol. 89. P. 2204-2209.

17. Abhangi M., Stankūnas G., Zychor I. Overview of the JET results. Nuclear Fusion. Vol. 55. No. 10. P. 1-14.

18. Stankūnas G., Batistoni P., Sjöstrand H., Conroy $S$. Measurements of fusion neutron yields by neutron activation technique: Uncertainty due to the uncertainty on activation cross-sections. Nuclear Instruments and Methods in Physics Research Section A. 2015. Vol. 788. P. 168-172.

19. Kačegavičius T., Urbonavičius E. Modelling of Ingress of Coolant Event into Vacuum Experiments with ASTEC Code. Journal of Fusion Energy. 2015. Vol. 34. Iss. 2. P. 320-325.

20. Povilaitis M., Kačegavičius T., Urbonavičius E. Simulation of the ICE P1 test for a validation of COCOSYS and ASTEC codes. Fusion Engineering and Design. 2015. Vol. 94. P. 42-47.

21. Urbonavičius E., Kaliatka T. Thermal-hydraulic assessment of W7-X plasma vessel venting system in case of $40 \mathrm{~mm}$ in-vessel LOCA. Science and Technology of Nuclear Installations. 2015. Vol. 2015, Article ID 240368, P. 1-9.
22. Kontautas A., Urbonavičius E. Accession of Lithuanian energy institute to nuclear fusion researches. The 6th International Renewable Energy Congress (IREC), March 24-26, 2015, Sousse-Tunisia. P. 4.

23. Alzbutas R., Voronov R. Reliability and safety analysis for systems of fusion device. Fusion Engineering and Design. 2015. Vol. 94. P. 31-41.

24. Alzbutas R., Voronov R. RAMI and PSA application for efficiency of fusion device. The 25th $\mathrm{Eu}$ ropean Safety and Reliability Conference (ESREL), September 7-10, 2015, ETH Zurich, Switzerland. London: Taylor \& Francis Group. P. 287-295.

25. Kaliatka T., Ušpuras E., Kaliatka A. Modelling of water ingress into vacuum vessel experiments using RELAP5 code. Journal of Fusion Energy. 2015. Vol. 34. Iss. 2. P. 216-224.

26. Kaliatka T., Ušpuras E., Kaliatka A. Integrated assessment of thermal hydraulic processes in W7-X fusion experimental facility. The 16th International Topical Meeting on Nuclear Reactor Thermal Hydraulics (NURETH-16), August 30 - September 4, 2015, Chicago, IL, USA. P. 6517-6529.

27. Kačegavičius T., Povilaitis M. The integral analysis of $40 \mathrm{~mm}$ diameter pipe rupture in cooling system of fusion facility W7-X with ASTEC code. Fusion Engineering and Design. 2015. Vol. 101. P. 141-147.

28. Povilaitis M., Kačegavičius T., Urbonavičius E. Simulation of the ICE P1 test for a validation of COCOSYS and ASTEC codes. Fusion Engineering and Design. 2015. Vol. 94. P. 42-47.

29. Stankūnas G., Tidikas A., Pereslavstev P., Catalánc J., Garcia R., Ogando F., Fischer U. Activity inventories and decay heat calculations for a DEMO with HCPB and HCLL blanket modules. Fusion Engineering and Design. 2016. Vol. 109-111, Part A. P. 347-352.

30. Kaliatka T., Ušpuras E., Kaliatka A. Modelling of pressure increase protection system for the vacuum vessel of W7-X device. Fusion Engineering and Design. 2016. Vol. 109-111, Part A. P. 114-118.

31. Dongiovanni D. N., Iešmantas T. Failure rate modeling using fault tree analysis and Bayesian network: DEMO pulsed operation turbine study case. Fusion Engineering and Design. 2016. Vol. 109-111. Part A. P. 613-617. 
Eugenijus Ušpuras, Sigitas Rimkevičius, Egidijus Urbonavičius, Algirdas Kaliatka, Gintautas Dundulis, Robertas Alzbutas, Gediminas Stankūnas, Mindaugas Vaišnoras, Virginijus Vileiniškis, Mantas Povilaitis, Tadas Kaliatka, Remigijus Janulionis, Renatas Karalevičius,

Roman Voronov, Tomas Iešmantas, Tomas Kačegavičius

\section{NUCLEAR FUSION RESEARCH AT} LITHUANIAN ENERGY INSTITUTE

\section{Summary}

Until Ignalina NPP was operational, most research activities at the Nuclear Installation Safety Laboratory (NISL) of the Lithuanian Energy Institute (LEI) were directed towards resolving of safety issues of nuclear power plants. Since 2006, LEI NISL researchers have become involved in research on nuclear fusion. Nuclear fusion is a process when two light nuclei, e. g. hydrogen isotopes deuterium and tritium, fuse together to form a new nucleus of helium, and during this process a huge amount of energy is released. Such process takes place in the stars, and scientists of the world are thinking how to control it and make use of it on the Earth.
In 2006, LEI NISL researchers implemented only a small project related with one of the safety aspects of ITER reactor; however, further LEI researchers increased their participation and became involved in new research areas: neutron transport, reliability of equipment, structural integrity of different structures, etc. Already in 2013, LEI NISL researchers together with other European research centres were developing a roadmap on how to achieve that nuclear fusion could be used for energy production by 2050 . This roadmap became a basis for Horizon 2020 programme EUROfusion project, which is co-ordinated by a research centre Max-Planck Institut für Plasmaphysik (Germany). This project is the largest not only in financial sense, but it is also the most ambitious research and innovation project of European Union.

This article presents a short review of each topic where LEI NISL researchers have performed research since 2006. At the end of the article, there is a list of the main publications by LEI NISL researchers.

Keywords: nuclear fusion, safety assessment, neutron transport, reliability of equipment, structural integrity research 